\title{
5. SEISMIC STRATIGRAPHIC FRAMEWORK OF THE LIMA AND YAQUINA FOREARC BASINS, PERU ${ }^{1}$
}

\author{
Mark W. Ballesteros, ${ }^{2}$ Gregory F. Moore, ${ }^{2}$ Brian Taylor, ${ }^{3}$ and Steve Ruppert ${ }^{3}$
}

\begin{abstract}
The stratigraphic framework of the Lima and Yaquina forearc basins offshore Peru, determined from multichannel seismic (MCS) data, reveals significantly different Neogene histories in the two basins. Miocene deposition in the Lima Basin was controlled mainly by variations in the relative subsidence rates. Depositional processes, particularly contour currents, may have had a major influence during the Pliocene-Pleistocene. In contrast, the Yaquina Basin shows no evidence of assumed contourites. Severe disruption of the reflectors indicates active tectonism throughout the Neogene in the Yaquina Basin, while reflectors representing late Miocene and younger strata in the Lima Basin are largely undeformed, which indicates relative quiescence.

Most sequences in the Lima Basin demonstrate the presence of a hinge line that separates the relatively thin, wedgeshaped landward part from a much thicker, lens-shaped seaward part. Generally, this hinge appears to represent a paleoslope break. Such hinge lines are not evident in the Yaquina Basin.

Both basins exhibit migration of the depocenters of the various sequences through time. The movement is to the south and landward in the Lima Basin, while migration is northward in the Yaquina Basin. These migrations appear to be the result of variations in the relative subsidence rates within the basins. In the Lima Basin these movements are closely related to structural features in the basement.

In addition to a structural trend that is oriented parallel to the margin, we observed a secondary structural trend that is oriented east-west. Development of structural features along this trend led to the development of two distinct depocenters in most of the stratigraphic sequences in the Lima Basin.
\end{abstract}

\section{INTRODUCTION}

This paper presents a three-dimensional stratigraphic framework for the Lima and Yaquina basins, based on the interpretation of a closely spaced grid of MCS data obtained during the Leg 112 site survey. Previous efforts were based either on isolated MCS lines (von Huene et al., 1985; Thornburg, 1985) or used single-channel analog data (Thornburg and Kulm, 1981).

The Lima Basin is located at a latitude between $10^{\circ}$ and $13^{\circ} \mathrm{S}$ on the upper slope of the Peruvian continental margin (Fig. 1). It is separated from the Salaverry Basin, which is located on the shelf, by a positive basement feature designated the outer-shelf high (Thornburg and Kulm, 1981). The data presented here cover only part of the Lima Basin (Fig. 1).

The Yaquina Basin is located at a latitude between $8^{\circ}$ and $10^{\circ} \mathrm{S}$ on the midslope part of the margin (Fig. 1). This basin is separated to the east from the upper-slope Trujillo Basin by a positive basement feature previously designated the upper-slope ridge (Thornburg and Kulm, 1981). Another basement high, oriented at approximately right angles to the trench, separates the Yaquina and Trujillo basins from the Lima Basin to the south. This feature can be seen in SeaMARC II images (Hussong et al., this volume) in the form of fractures and fault scars on the seafloor.

\section{METHODS}

Data acquisition and processing are discussed by Moore and Taylor (this volume). Figures 2 and 3 illustrate the data grids. We identified seismic sequences using the techniques described by Mitchum and Vail (1977) and Mitchum et al. (1977). In the Yaquina Basin, problems with structural disruption and data acquisition (see Moore and Taylor, this volume) greatly reduced

${ }^{1}$ Suess, E., von Huene, R., et al., 1988. Proc. ODP, Init. Repts. , 112: College Station, TX (Ocean Drilling Program).

2 Department of Geosciences, University of Tulsa, Tulsa, OK 74104.

${ }^{3}$ Hawaii Institute of Geophysics, 2525 Correa Rd., Honolulu, HI 96822. data resolution, making precise definition of reflector relationships difficult.

The limited age constraints for various sequences are based on the Leg 112 drilling results and are supplemented with ages determined from dredge samples (Kulm et al., this volume). In particular, we used data from Sites 679,682 , and 688 (Fig. 2) to project ages in the Lima Basin and results from Sites 683 and 684 (Fig. 3) for estimates in the Yaquina Basin. We constructed a series of isochron and selected time-structure maps for each basin. Fault patterns were simplified or eliminated completely for the sake of clarity.

\section{LIMA BASIN}

We divided the strata in the Lima Basin into 11 seismic stratigraphic units. These units are summarized in Table 1. We selected only the most prominent sequence boundaries. In most cases, the indicated sequences can be subdivided further. The more important attributes of each sequence are discussed next.

\section{Sequence L1}

Sequence $\mathrm{L} 1$ is composed of parallel reflectors having high amplitude and fair-to-good continuity (e.g., line 14, Plate 1A, in back pocket). Upper reflectors are generally conformable, although truncations can be seen locally in the sequence. No attempt was made to define the base of this sequence because of poor data resolution. Based on similarities to a comparable sequence penetrated in the Yaquina Basin and tentative correlations with Sites 682 and 688 , we believe that sequence L1 represents middle Eocene deposits. For our purposes, we considered these deposits as acoustic basement.

The time-structure map at the top of sequence L1 (Fig. 4) shows a relatively even slope on the landward parts. A north/ northwest-trending horst, designated the landward ridge (LR), can be seen in line 14 at 0810 UTC (Plate 1A) and in line 13 at 0100 UTC (Plate 1A). Line 22 runs along the axis of this ridge. Another positive basement feature, called the seaward ridge (SR), trends subparallel to the LR, while line 20 runs along its axis. 


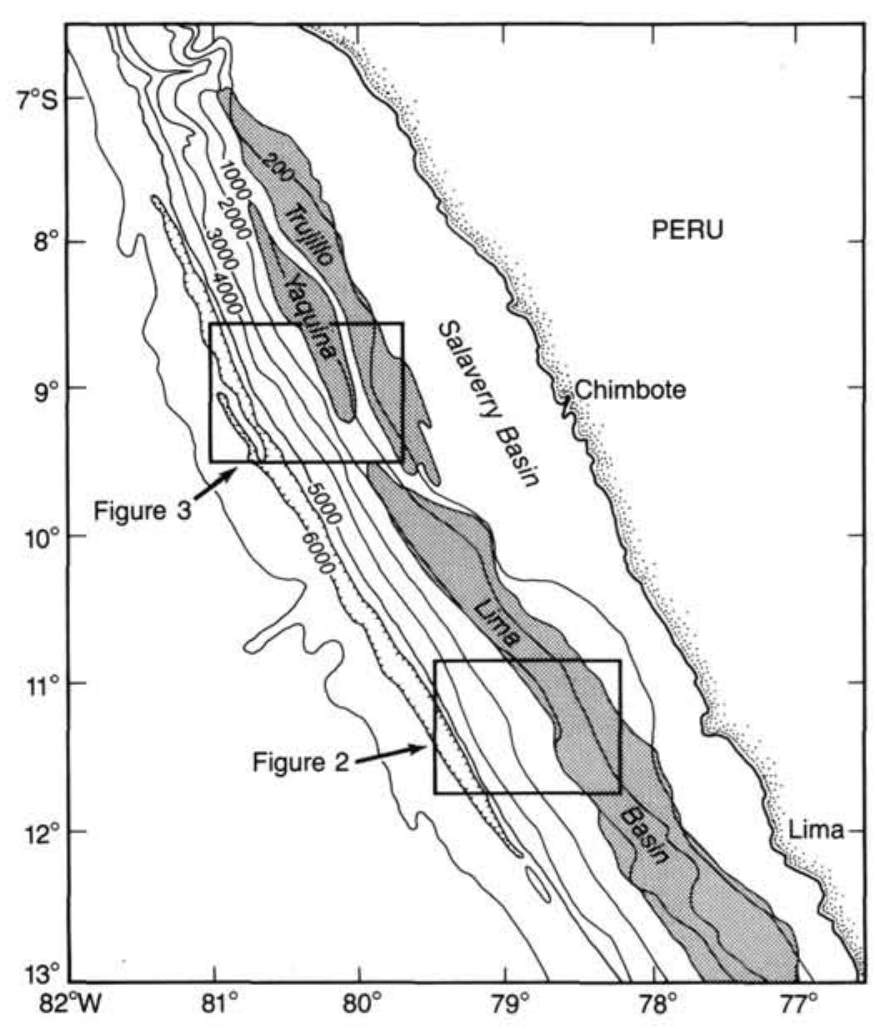

Figure 1. Continental margin off central Peru showing the location of the Lima, Trujillo, and Yaquina forearc basins; modified after Thornburg and Kulm (1981). Note the location of Figures 2 and 3, indicated by the boxes.

The SR corresponds to the upper-slope ridge of Thornburg and Kulm (1981). We interpreted the SR as a series of tilted fault blocks rather than a single coherent ridge, based on the sediment truncation patterns in the sequence L2 isochron (Fig. 5). Two subbasins about $400 \mathrm{~m}$ deep can be seen in the low area between the LR and SR, relative to an east/west-trending interridge saddle (IRS).

\section{Sequence $\mathbf{L} 2$}

Sequence L2 is characterized by subparallel reflectors of variable continuity and amplitude (e.g., line 14, Plate 1A). These reflectors are broken, discontinuous, and sharply angular to the overlying sequence boundary. Correlation with Site 679 indicates that this sequence is composed of low-energy turbidites of middle Miocene age.

Reflectors onlap along the flanks of both ridges, which indicates that these were structural highs during deposition. In many places, the SR lacks sediments of sequence L2, while the LR has a thin but persistent sediment cover (Fig. 5).

Numerous faults dissect sequence L2 (e.g., line 14, Plate 1A). Simplified fault patterns (Figs. 4 and 5) indicate that at least two structural trends exist, one approximately north-northwest and almost parallel to the trench, and a subordinate one oriented east-southeast and parallel to the IRS.

The sequence L2 isochron map (Fig. 5) indicates two major depocenters. One is on the landward side of the LR, trends eastwest, and has its deepest part at the north end of the study area. The other occurs along the seaward flank of the LR and trends northwest-southeast.

\section{Sequence L3}

The lower boundary of sequence L3 represents an unconformity surface of early-late Miocene age that spans the interval from 8 to 11 m.y. (Fig. 6; R. von Huene, pers. commun., 1987). This sequence marks a distinct change in seismic character (e.g., line 14 , Plate $1 \mathrm{~A})$. It is substantially less disrupted than the underlying strata. Reflectors diverge locally and indicate syn-depositional subsidence. Sequence L3 laps out to the east (seaward of Site 679), which suggests correlation with the latest part of the early-late Miocene hiatus noted at Site 679.

The landward part of sequence L3 resembles a wedge, while the seaward part of the sequence is an elongated but more irregular lens. The hinge line, or inflection point, that separates the two areas almost coincides with the landward flank of the SR (Fig. 7). Note the east-west trend in sequence L3, which is superimposed on the more prominent trend parallel to the trench (Fig. 7). Reflector terminations indicate onlap fill and are directed away from the depocenters and toward the intervening thin areas. In the more uniform landward part of the sequence, reflectors onlap toward the east, i.e., landward (Plate 1A, line 14; Fig. 7). Upper terminations are generally conformable, but erosional truncation is evident locally. This indicates that the sequence either was deposited near sea level or was subjected to submarine erosion. Additional evidence in sequence L4 supports the former hypothesis. The landward lapping out of the sequence thus may represent a paleoshoreline. Reflector characters vary greatly, but amplitudes are generally moderate to low, while continuity is fair to good in the landward part of the sequence. Seaward, the reflector character becomes more discontinuous and disrupted with decreasing amplitude. This type of reflector character is typical of shelf deposits (Sangree and Widmier, 1977) and is consistent with other evidence. The disrupted nature of the reflectors probably is related to differential subsidence of the basin.

The isochron map of sequence L3 (Fig. 7) shows a well-developed, thickened section that trends north-south and is centered over the SR in the northern part of the study area. Another depocenter is located over the SR near line 23 in the southern part of the study area. This observation indicates nonuniform subsidence of the SR and that the northern and southernmost parts have subsided more rapidly than the central area. The eastward bulge in the seaward truncation of the sequence around line 14 on the isochron map (Fig. 7) and the seaward onlap of reflectors in line 14 at 1100 UTC (Plate 1A) corroborate this observation. Note that the maximum thickness of sequence L3 occurs where the upper-sequence boundary is truncated at the seafloor. This is indicated in the lines north and south of line 14 (Fig. 7). Thus, the rapid thinning seen from this point seaward is partly erosional or nondepositional. Such truncation occurs in many of the Lima Basin sequences (e.g., lines 13 and 14 , Plates $1 \mathrm{~A}$ and $1 \mathrm{~B})$.

Sequence L3 also shows significant thickening in the northeastern part of the study area, which suggests formation of another subbasin. A structural high can be seen in the landward part of the sequence. This is supported by the reversal of onlap directions along line 22 (Plate 1C, 0730-0810 UTC) near the intersection with line 13 (Fig. 7). The trend of this high is approximately east-west, which indicates a relationship to the east-west trend in the seaward part of the sequence. The isolated depocenter depicted in Figure 8 (over line 12 between lines 20 and 22) is related to thickening on the north side of the IRS and indicates local reactivation of the faults along this feature during deposition of sequence L3.

\section{Sequence $\mathbf{L 4}$}

As with sequence L3, sequence L4 has wedge-shaped and elongated lens-shaped parts. However, the seaward part of the sequence is much less irregular. The inflection point that marks the transition between the two parts (Fig. 8) represents a paleoslope break and is significantly farther seaward than this same point in sequence L3. Results from Site 679 indicate that the 


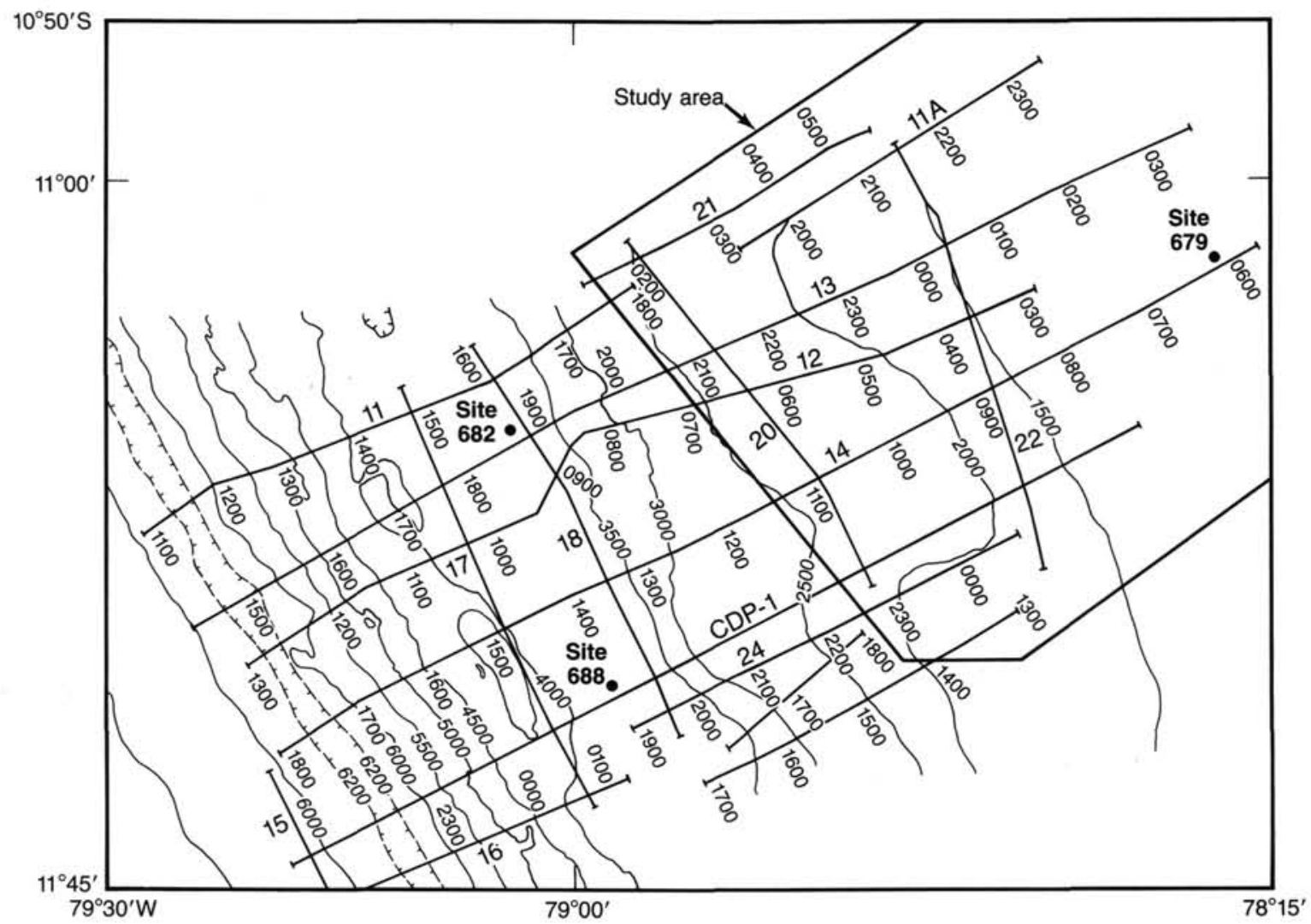

Figure 2. Navigation chart for the Lima Basin survey. Line numbers are indicated next to the respective lines. The Seiscom Delta multichannel seismic (MCS) line acquired in 1973 during the Nazca Plate Project is labeled CDP-1. Bathymetry is based on the SeaMARC II survey (Hussong et al., this volume). Note the locations of ODP Sites 679, 682, and 688 .

landward part of the sequence consists of upper Miocene deposits related to upwelling.

Relative subsidence of the landward part of the basin can be seen in the seaward onlapping of lower terminations onto a topographic high (e.g., line 14, 0735-0800 UTC, Plate 1A), which coincides with the area in which sequence LH sediments are absent (Fig. 8). The reversal of the onlapping direction in lines 12 and 22 (Plate 1C, 0930 UTC) occurs over the IRS and suggests that this feature used to be structurally prominent. The persistence of landward onlapping noted in line 13 (Plate 1B, 01000250 UTC; Fig. 8) further indicates that the northeastern part of the study area was relatively stable, while the southeastern part subsided. Line 22 also shows southward onlapping at the southern end (Plate 1C, 1115 UTC; Fig. 8), which suggests that the depression created by relative subsidence may have been limited in southern extent.

A thick lens of sediments seaward of this inflection can be seen in the sequence L4 isochron map (Fig. 8). This lens is divided into two major depocenters. The northern lobe is about $300 \mathrm{~ms}$ thick and contains onlapping, subparallel reflectors of variable amplitude and fair continuity, which indicates an environment of low-energy deposition. This southern lobe is about $400 \mathrm{~ms}$ thick and is further subdivided by a northwest/southeast-trending area of relatively thin sediment cover (Fig. 8). The reflectors in the northern part of this southern depocenter are hummocky in character and downlap seaward in line 14 (Plate 1A, 1015-1130 UTC) and CDP-1, which could indicate progradation. Sediments in this area probably came from the adjacent structural high, where no sequence L4 sediments occur (Fig. 8). These sediments were deposited under relatively high-energy depositional conditions. Both the absence of sediments from se- quence L4 in this area and the character of the seismic data suggest deposition in a shelf environment. Farther south, a thick trough of sediment extends landward, which delineates a substantial reentrant. Reflectors in line 23 demonstrate slope-front fill in this area. Onlapping reflectors in line 24 and on the seaward side of the southeast-trending ridge in CDP-1 (Fig. 8) indicate low-energy deposition.

\section{Sequence L5}

Sequence L5 was subdivided into lower, middle, and upper subsequences, designated L5L, L5M, and L5U. Subsequence L5L (Fig. 9) is restricted to the northern part of the study area and subsequence L5M (Fig. 10) to the southern part, while subsequence L5U (Fig. 11) covers the entire study area. The relative age of L5L and L5M is established by the onlapping of L5M reflectors onto those of L5L in line 22 (Plate 1C, 0840 UTC). This is the only point where these two subsequences intersect in the data discussed here. Apparently, a structural high occurred subparallel to line 13, which separated the two. While reflector relationships indicate that the uppermost strata of subsequence L5M are younger than those of $\mathrm{L} 5 \mathrm{~L}$, it is likely that deposition of the older parts of these two subsequences was contemporaneous. Preliminary correlation with Site 679 indicates a late Miocene age for subsequence $\mathrm{L} 5 \mathrm{U}$, the only subsequence penetrated.

Subsequence L5L (Fig. 9) resembles an east-northeast-trending trough. The lower part of L5L contains parallel reflectors of moderate amplitude and good continuity. The basal reflector generally conforms to the lower sequence boundary, although low-angle landward onlapping can be seen in the seaward part of the sequence. These characteristics suggest shelf deposits. Seaward thickening of this part of subsequence L5L results from 


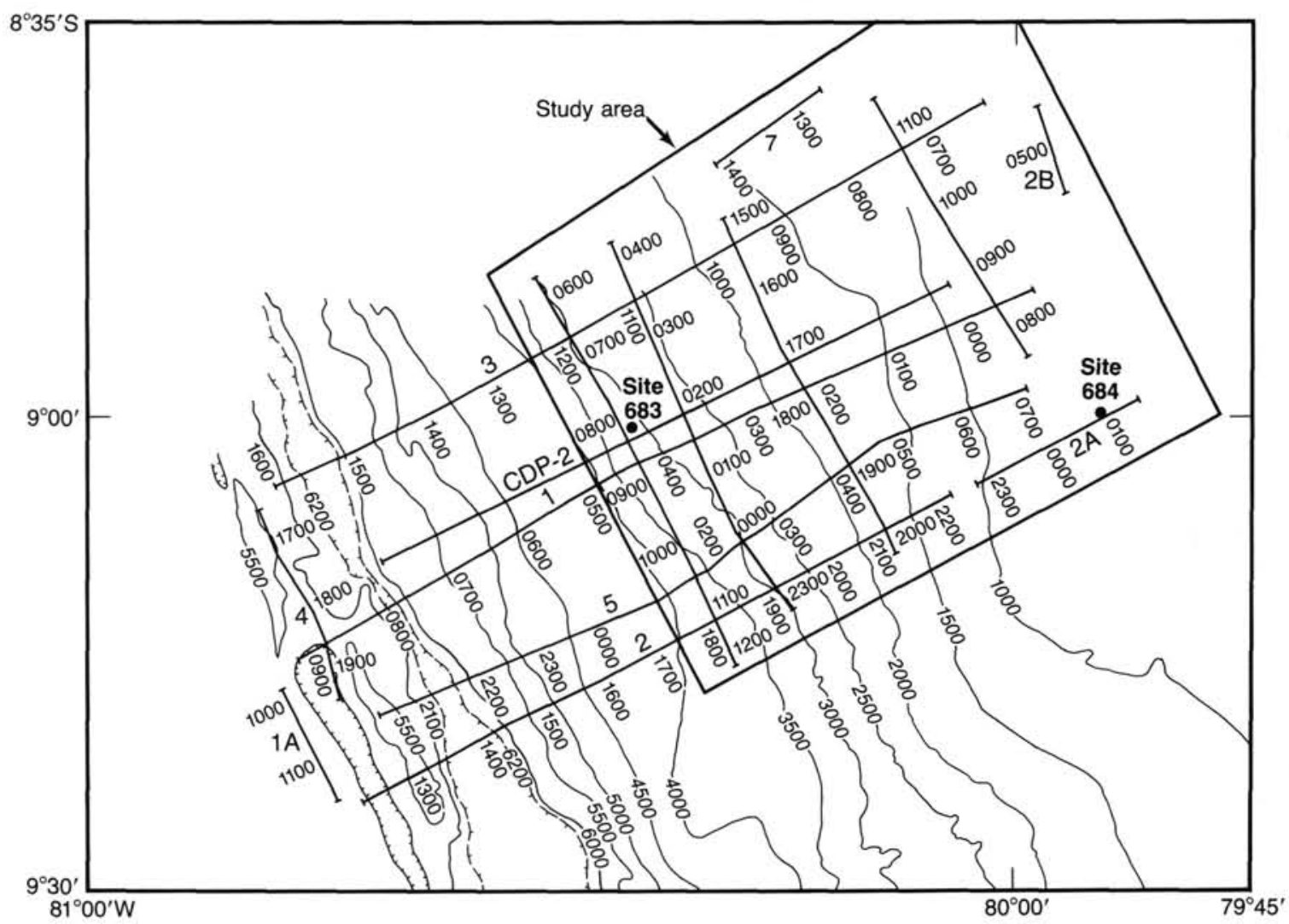

Figure 3. Navigation chart for the Yaquina Basin survey. Line numbers are indicated next to the respective lines. The Seiscom Delta MCS line acquired in 1973 during the Nazca Plate Project is labeled CDP-2. Bathymetry is based on the SeaMARC II survey (Hussong et al., this volume). Note the location of ODP Sites 683 and 684.

erosionally truncated reflectors added above this basal event. This suggests shallow-water deposition and reinforces our interpretation of shelf deposits. In contrast, the upper part of L5L shows landward-onlapping reflectors of lower amplitude and continuity, which is characteristic of low-energy basin fill. Without evidence of diverging reflectors, discrete pulses of subsidence instead of gradual syn-depositional subsidence are suspected. Thus, two pulses of subsidence can be seen: an early one that resulted in relative northward subsidence and a later one that caused relative seaward subsidence. Reflectors form a mound that shows both landward and seaward downlapping in line 13 (Plate 1B, 0030 UTC). This may indicate confined deposition on the downthrown side of the seaward-bounding fault of the LR. Rapid relative subsidence in the northern part of the study area may have caused sediments to be funneled into the area from the south along the base of this fault scarp.

Relative subsidence of the southern part of the study area caused initial deposition of sequence L5M. The two depocenters in the L5M isochron (Fig. 10) show that relative subsidence was greater in these areas. The intervening ridge is parallel to the SR, but offset slightly toward land. Reflectors in the landward basin have fairly low amplitude and good continuity and onlap in all directions. In contrast, reflectors in line 14 seaward of the intervening ridge downlap seaward (Plate 1A, 1040-1110 UTC). Similar clinoforms are evident in CDP-1. Here they make up only the upper part of the sequence and overlie subparallel reflectors of moderate amplitude and continuity that show landward onlapping. This division also can be seen in line 20 , where onlapping reflectors are evident between CDP-1 and line 14 and thicken southward. Line 24 shows only the lower, onlapping reflectors. These suggest two phases of deposition, i.e., an early low-energy one and a later, higher-energy one during which sediments prograded seaward and to the south from a source near the intersection of line 14 with the shelf break (Fig. 10). These two phases may be related to those in subsequence L5L.

Subsequence L5U (Fig. 11) has an external geometry similar to the underlying sequences, with a thin, wedge-shaped landward part and a much thicker, lens-shaped seaward section. Internal reflector geometry contrasts strikingly with that of the underlying sequences. Dip lines show faint seaward-downlapping and prominent landward-downlapping terminations (Fig. 11; line 14, Plate 1A, 0950 UTC). This landward downlapping suggests contourite deposits. However, without a strong linear trend and asymmetric mound geometry, this interpretation is weak. Reflector character also is hummocky and has low-tomoderate amplitude and variable continuity. This is not characteristic of contourites. We believe that these terminations represent onlapping reflectors that later were tilted to their present position by relative landward subsidence.

Reflectors in lines 13 (Plate 1B, 0100-0120 UTC) and 14 (Plate 1A, 0715-0800 UTC) lap on the shoreward side of the LR (Fig. 11). This suggests a structural high at the time of deposition. These reflectors later were tilted downward by relative subsidence of the LR. Line 22 (Plate 1C, 0930 UTC) shows bimodal onlap centered around a prominent basement feature and associated fault. Today, orientation of the reflectors indicates that they tilted south after deposition. Just seaward of the LR in line 13 (Plate 1B, 0120-0140 UTC), reflectors drape over the underlying strata, which indicates hemipelagic deposition. We believe that the LR acted locally as a buttress behind which sediments ponded. This resulted in onlapping reflectors on the landward side and conformable drape on the seaward side. Correlation 
Table 1. Profile of sequences found at Lima Basin.

\begin{tabular}{|c|c|c|c|c|c|}
\hline \multirow[b]{2}{*}{ Sequence } & \multicolumn{2}{|c|}{ Terminations $^{\mathrm{a}}$} & \multirow{2}{*}{$\begin{array}{c}\text { Seismic } \\
\text { characteristics }\end{array}$} & \multirow[b]{2}{*}{ Facies } & \multirow[b]{2}{*}{ Age } \\
\hline & upper & lower & & & \\
\hline LI & $\mathrm{C} / \mathrm{Te}$ & $?$ & $\begin{array}{l}\text { Subparallel, disrupted, high } \\
\text { amplitude, fair-to-good } \\
\text { continuity. }\end{array}$ & $\begin{array}{l}\text { Shelf } \\
\text { deposits }\end{array}$ & $\begin{array}{l}\text { middle } \\
\text { Eocene }\end{array}$ \\
\hline L2 & $\mathrm{Te}$ & On & $\begin{array}{l}\text { Subparallel, variable } \\
\text { amplitude and continuity, } \\
\text { highly disrupted locally, } \\
\text { wedge to elongate lens. }\end{array}$ & $\begin{array}{l}\text { Low-energy } \\
\text { turbidites }\end{array}$ & $\begin{array}{l}\text { middle } \\
\text { Miocene }\end{array}$ \\
\hline \multirow[b]{2}{*}{ L4 } & $\mathrm{C} / \mathrm{Te}$ & On & $\begin{array}{l}\text { Subparallel, continuity } \\
\text { and amplitude are } \\
\text { low to moderate, } \\
\text { decreasing seaward. } \\
\text { Locally disrupted, chaotic } \\
\text { external form, wedge to } \\
\text { elongate lens. }\end{array}$ & $\begin{array}{l}\text { Shelf } \\
\text { deposits }\end{array}$ & $\begin{array}{l}\text { late } \\
\text { Miocene }\end{array}$ \\
\hline & $\mathrm{C}$ & $\mathrm{On} / \mathrm{Dn}$ & $\begin{array}{l}\text { Subparallel, variable } \\
\text { amplitude and continuity, } \\
\text { hummocky clinoforms, } \\
\text { external form, wedge to } \\
\text { elongate lens. }\end{array}$ & $\begin{array}{l}\text { Upwelling } \\
\text { deposits, slope } \\
\text { front fill, low- } \\
\text { energy shelf/ } \\
\text { slope deposits }\end{array}$ & $\begin{array}{l}\text { late } \\
\text { Miocene }\end{array}$ \\
\hline \multirow[t]{4}{*}{ L5L } & $\mathrm{C} / \mathrm{Te}$ & On & $\begin{array}{l}\text { Subparallel, fair to } \\
\text { good amplitude and } \\
\text { continuity. }\end{array}$ & $\begin{array}{l}\text { Low-energy } \\
\text { shelf/slope } \\
\text { deposits, } \\
\text { upwelling } \\
\text { deposits(?) }\end{array}$ & $\begin{array}{c}\text { late } \\
\text { Miocene }\end{array}$ \\
\hline & C & $\mathrm{On} / \mathrm{Dn}$ & $\begin{array}{l}\text { Subparallel, oblique } \\
\text { clinoforms evident locally, } \\
\text { low to moderate amplitude, } \\
\text { continuity fair to good, } \\
\text { decreasing seaward, } \\
\text { external form, wedge to } \\
\text { elongate lens. }\end{array}$ & $\begin{array}{l}\text { Variable energy } \\
\text { shelf/slope } \\
\text { deposits, } \\
\text { upwelling } \\
\text { deposits(?) }\end{array}$ & $\begin{array}{c}\text { late } \\
\text { Miocene }\end{array}$ \\
\hline & $\mathrm{C}$ & On/Dn(?) & $\begin{array}{l}\text { Subparallel to diverging, } \\
\text { low to moderate amplitude, } \\
\text { fair to good continuity, } \\
\text { external form wedge to } \\
\text { lens, prominent landward } \\
\text { downlap(?) in lens, } \\
\text { local draping evident. }\end{array}$ & $\begin{array}{l}\text { Low-energy } \\
\text { shelf/slope } \\
\text { deposits, } \\
\text { contourites(?), } \\
\text { hemipelagic, } \\
\text { upwelling } \\
\text { deposits }\end{array}$ & $\begin{array}{c}\text { late } \\
\text { Miocene }\end{array}$ \\
\hline & $\mathrm{C} / \mathrm{Te}$ & $\mathrm{Dn} / \mathrm{On}$ & $\begin{array}{l}\text { Subparallel to diverging, } \\
\text { fair to good amplitude } \\
\text { and continuity, wedge }\end{array}$ & $\begin{array}{l}\text { Contourites, } \\
\text { upwelling } \\
\text { deposits(?) }\end{array}$ & $\begin{array}{c}\text { early } \\
\text { Pliocene }\end{array}$ \\
\hline L6 & & & $\begin{array}{l}\text { to asymmetric mound } \\
\text { form, prominent landward } \\
\text { downlap in mound. }\end{array}$ & & \\
\hline L7 & C & On & $\begin{array}{l}\text { Subparallel, locally } \\
\text { divergent, fair to good } \\
\text { amplitude and continuity, } \\
\text { lens to trough form. }\end{array}$ & $\begin{array}{l}\text { Low-energy } \\
\text { turbidites, } \\
\text { upwelling } \\
\text { deposits }\end{array}$ & Pliocene \\
\hline L8 & $\mathrm{C} / \mathrm{Te}$ & On & $\begin{array}{l}\text { Subparallel, locally } \\
\text { divergent, fair to good } \\
\text { amplitude and continuity, } \\
\text { lens to trough form. }\end{array}$ & $\begin{array}{l}\text { Low-energy } \\
\text { turbidites, } \\
\text { upwelling } \\
\text { deposits }\end{array}$ & $\begin{array}{l}\text { Pliocene- } \\
\text { Pleistocene }\end{array}$ \\
\hline L9 & $\mathrm{C} / \mathrm{Te}$ & On & $\begin{array}{l}\text { Subparallel, locally } \\
\text { divergent, fair to good } \\
\text { amplitude and continuity, } \\
\text { lens to trough form. }\end{array}$ & $\begin{array}{l}\text { Low-energy } \\
\text { turbidites, } \\
\text { upwelling } \\
\text { deposits }\end{array}$ & Pleistocene \\
\hline
\end{tabular}

${ }^{\mathrm{a}} \mathrm{C}=$ conformable; $\mathrm{Te}=$ erosional truncation; $\mathrm{On}=$ onlap; $\mathrm{Dn}=$ downlap.

with Site 679 shows that the landward part of the sequence is composed of upwelling-related deposits.

The seaward part is divided into northern and southern depocenters. As in sequence L4, the southern depocenter is further subdivided by a prominent east-west-trending, thin sediment cover (Fig. 11) that coincides with the IRS. As a result, the individual features seen in the southern depocenter in the isochron map (Fig. 11) have significant east-west components. However, the general trend of the seaward part of the sequence is parallel to the trench. Onlapping of reflectors onto both sides of the structural high over the IRS can be seen in lines 22 (Plate 1C, 0900-0950 UTC) and 14 (Plate 1A, 0900-1000 UTC).

\section{Sequence L6}

Sequence L6 is more limited areally than underlying sequences. This sequence is present in a single depocenter that is located directly over the thin cover in the underlying sequence (Fig. 12). This suggests relative subsidence of the IRS. The external geometry again shows a fairly thin, wedge-shaped land- 


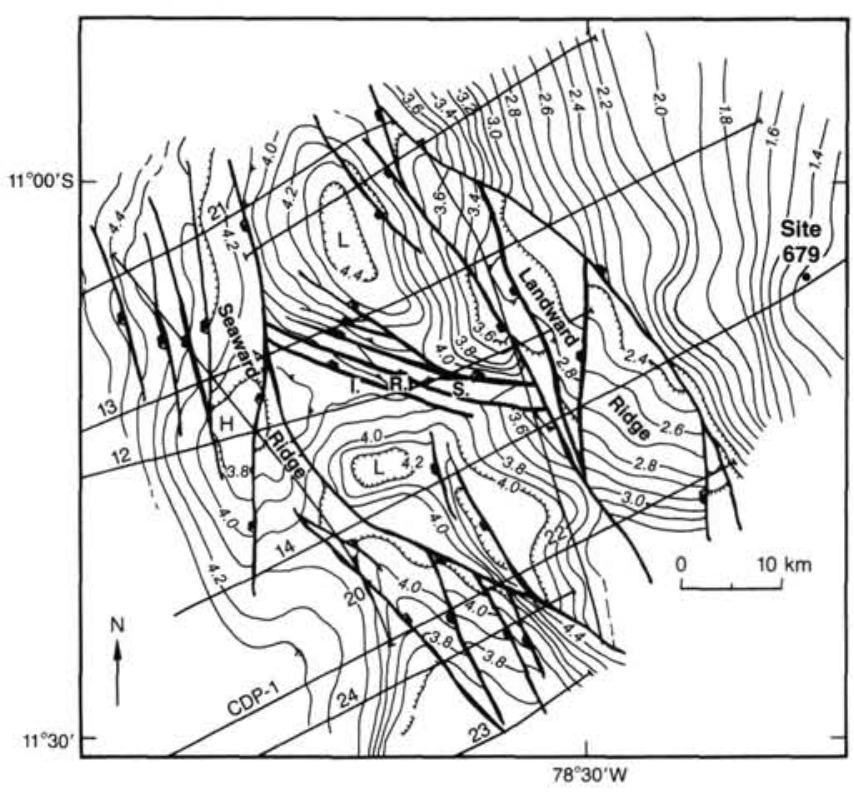

Figure 4. Time-structure map at top of sequence L1. Fault patterns have been greatly simplified. Note the location of the landward ridge (LR), seaward ridge (SR), and inter-ridge saddle (IRS). Note also the two subbasins located between the LR and SR, one north of the IRS and the other to the south. Isochrons are in seconds of two-way traveltime: $\mathrm{L}=$ low; $\mathrm{H}=$ high. Location of seismic lines is indicated. Contour interval is $0.1 \mathrm{~s}$. See text for discussion.

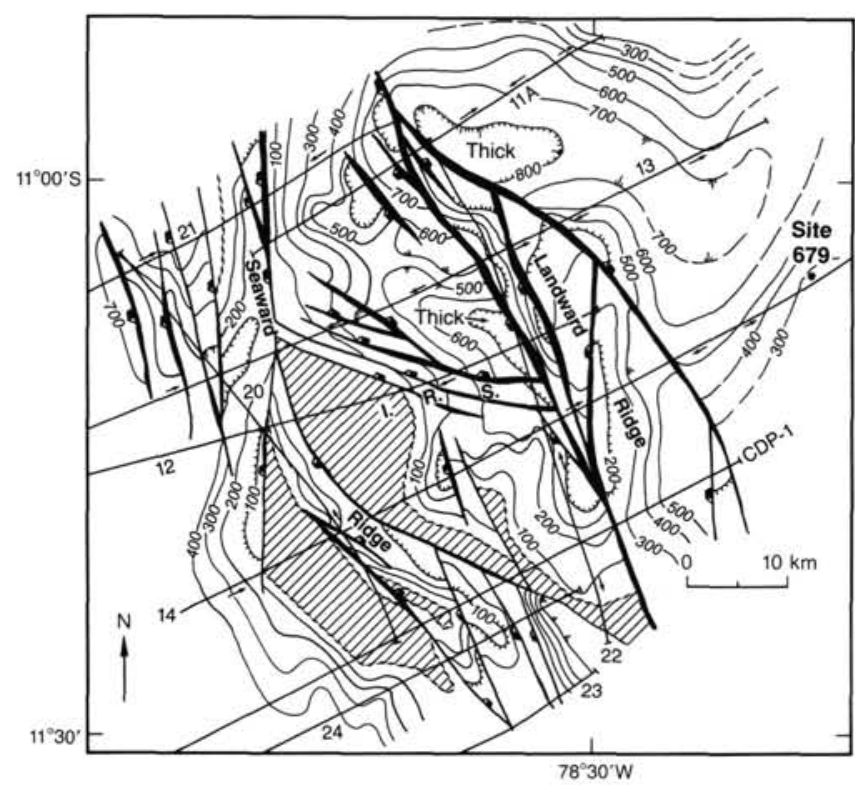

Figure 5. Isochron map of sequence L2. Hatched area indicates absence of sediments of this age. Arrows indicate the truncation direction of baselapping reflectors. We interpret these as onlapping unless otherwise noted; however, post-depositional tectonic movement and poor data resolution make this determination speculative. Symbols on the faults indicate the downthrown side. All faults indicated are normal. Note the location of the LR, SR, and IRS. Isochrons are in milliseconds of twoway traveltime. Interval is $100 \mathrm{~ms}$. See text for discussion.

ward part and a thicker, lens-shaped seaward part. Reflector geometries along line 22 (Plate 1C, 0820-0930 UTC) show onlapping in both directions away from a central graben, which indicates relative subsidence along the bounding faults.

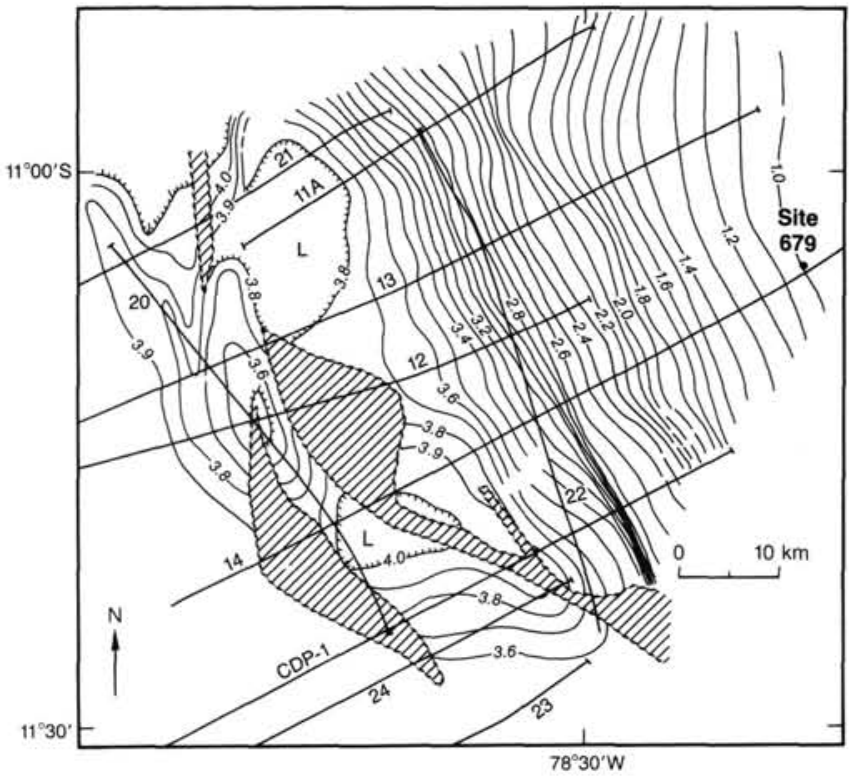

Figure 6. Time-structure form map at base of sequence L3. This corresponds to the post-middle Miocene unconformity surface. Faulting is not shown for clarity and simplicity. Hatched area indicates areas in which sequence-L2 strata are absent beneath the unconformity. Note the correspondence of the southern structural low and the large area in which sequence- $\mathrm{L} 2$ sediments are absent, which indicates a topographic reversal. Isochrons are in seconds of two-way traveltime. Interval is $0.1 \mathrm{~s}$. See text for discussion.

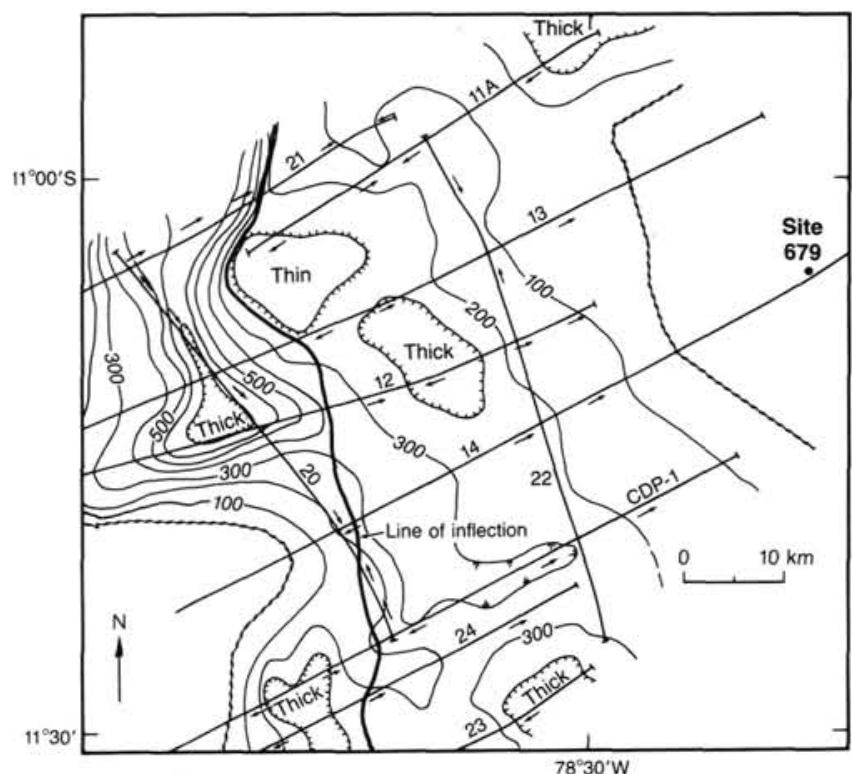

Figure 7. Isochron map of sequence L3. Annotation is the same as that in Figure 5. Note the inflection between the landward and seaward parts of the sequence, indicated by the heavy line. We interpreted this inflection as a paleoslope break. Isochrons are in milliseconds of two-way traveltime. Interval is $100 \mathrm{~ms}$. See text for discussion.

The seaward part of sequence L6 shows landward-downlapping terminations. Unlike similar reflectors in subsequence L5U, sequence L6 does have well-developed linear and asymmetric mound morphologies. In addition, the reflectors have high amplitude and continuity, which suggests internal terminations locally (line 14, Plate 1A, 0930-1010 UTC). We interpreted these 


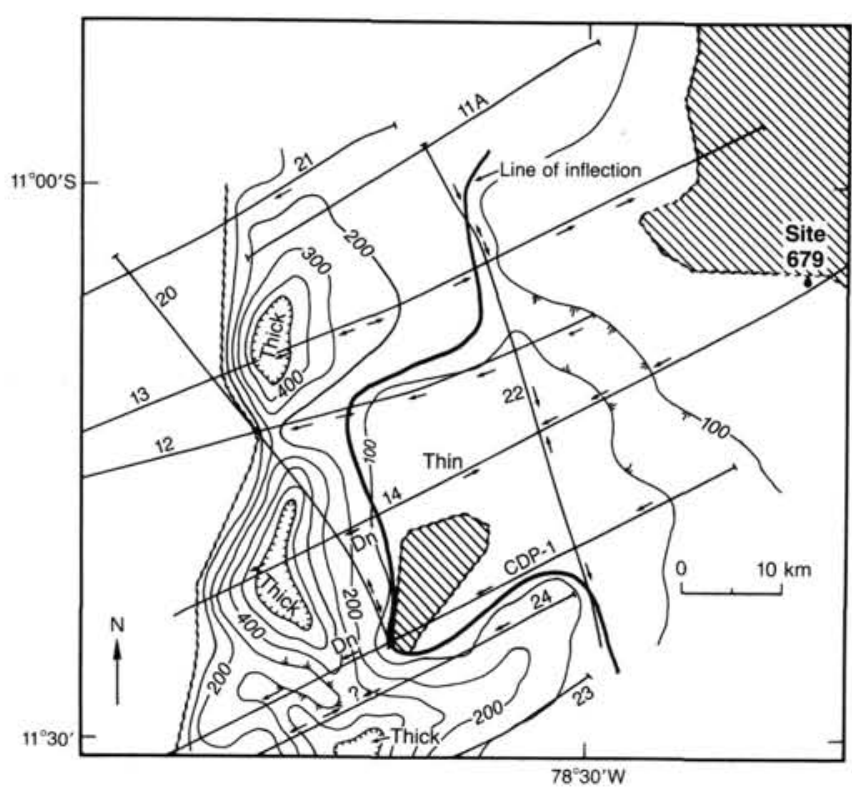

Figure 8. Isochron map of sequence L4. Annotation is the same as that in Figure 6. Note the inflection between the landward and seaward parts of the sequence, indicated by the heavy line. We interpreted this inflection as a paleoslope break. Contours are in milliseconds of two-way time. Contour interval is $100 \mathrm{~ms}$. See text for discussion.

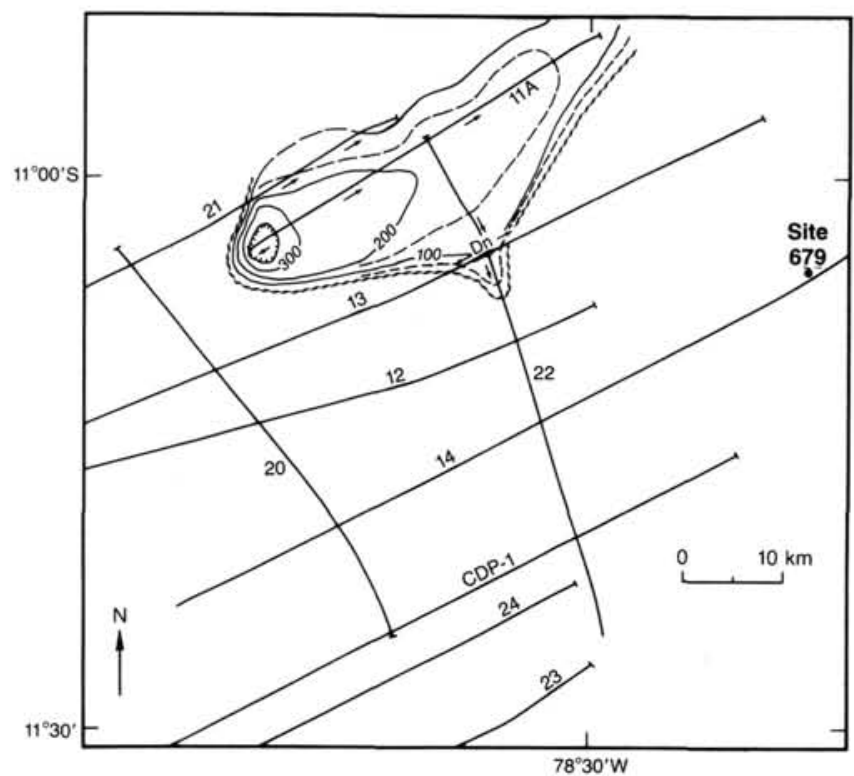

Figure 9. Isochron map of sequence L5L. Annotation is the same as that in Figure 6. Contours are in milliseconds of two-way time. Contour interval is $100 \mathrm{~ms}$. Dashed contours are $50 \mathrm{~ms}$. See text for discussion.

reflectors as contourite deposits (Mitchum and Vail, 1977). These reflectors also closely resemble contourite deposits identified in the Blake Outer Ridge (Shipley et al., 1978). Unlike the contourites of the Blake Outer Ridge, these reflectors were modified by rapid, nonuniform subsidence.

We cannot rule out the possibility that sequence $L 6$ resulted from rapid landward subsidence, as was assumed for L5U. However, significant differences in shape and character do exist between subsequence L5U and sequence L6. L5U thickens rapidly and then becomes fairly uniform, while L6 thickens persist-

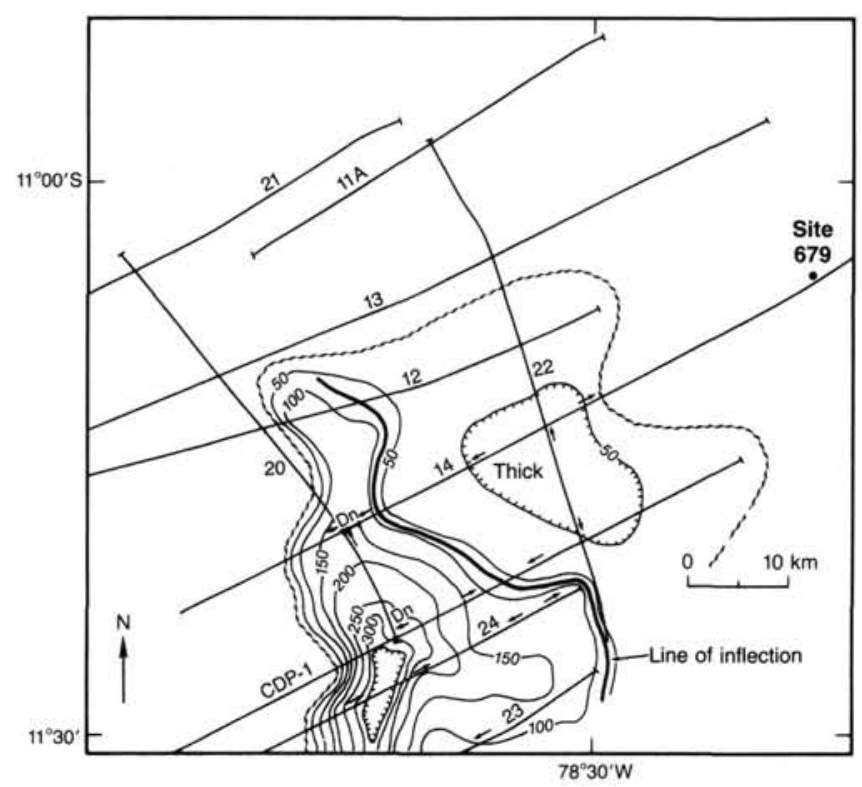

Figure 10. Isochron map of sequence L5M. Annotation is the same as that in Figure 6. Note the inflection between the landward and seaward parts of the sequence, indicated by the heavy line. We interpreted this inflection as a as a paleoslope break. Contours are in milliseconds of two-way time. Contour interval is $50 \mathrm{~ms}$. See text for discussion.

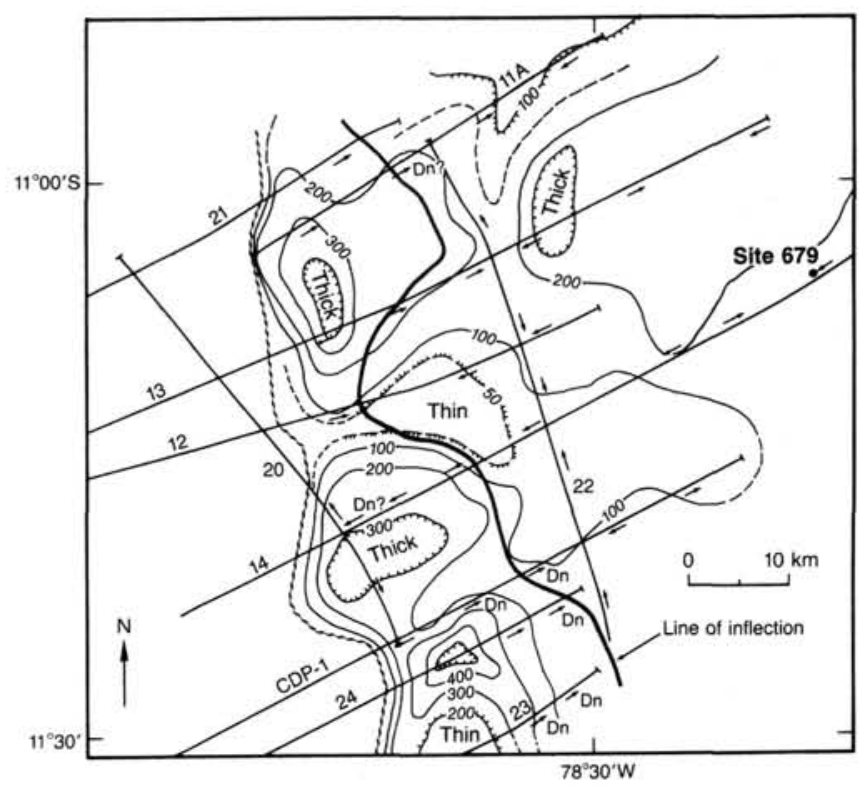

Figure 11. Isochron map of sequence L5U. Annotation is the same as that in Figure 6. Note the inflection between the landward and seaward parts of the sequence, indicated by the heavy line. We interpreted this inflection as a paleoslope break. Contours are in milliseconds of twoway time. Contour interval is $100 \mathrm{~ms}$. Dashed contours are $50 \mathrm{~ms}$. See text for discussion.

ently. If these downlapping terminations in sequence L6 do represent onlapping, the existence of a substantial barrier seaward of the Lima Basin behind which sediments could pond is implied. We could find no evidence for this. In addition, massive amounts of material would have to be removed by slumping or erosion. While some evidence of slumping on the slope seaward of the Lima Basin was noted (von Huene et al., 1987a), the 
slumping was dated as middle to late Miocene. This is older than one would expect if the source was sequence L6 sediments, which we interpreted as lower Pliocene.

Finally, the steepness and large number of downlapping reflectors suggest that substantial amounts of localized subsidence must have occurred to give today's configuration. Without evidence of such localized, large-scale subsidence in the underlying strata, we believe that this process was not responsible. For example, the post-middle Miocene unconformity surface is smooth instead of depressed locally beneath the L6 inflection (e.g., line 14, Plate 1A).

As in sequence L5, an inflection is evident in line 14 (Plate 1A, 0930 UTC) at the transition between the contourite mounds and the landward part, where basal terminations onlap. The consistent landward onlapping of sequence L6 indicates seaward subsidence in the study area. Results from Site 679 again indicate upwelling-related deposits in the landward part of the section. Locally, the upper reflectors seem erosionally truncated rather than conformable, as noted in the underlying sequences. Correlation with Site 679 indicates that this sequence was probably deposited during the early Pliocene.

\section{Sequence $\mathbf{L 7}$}

Sequence L7 marks a distinct change in the depositional regime. This takes the form of a southward-dipping trough (Fig. 13) having a linear mound constructed by contourites to act as the seaward-bounding element (line 14, 0930 UTC, Plate 1A). We observed two depocenters. The saddle between the two depocenters corresponds to the IRS. Reflectors onlap both seaward and landward, away from the central axis. A subtle paleohigh is indicated in the northeastern part of the sequence by seaward-onlapping reflectors at the landward ends of lines $11 \mathrm{~A}$ and 13 (Fig. 13). Line 22 shows onlapping to the north (Plate $1 \mathrm{C})$. When combined with general thickening of the sequence to the south, renewed relative southward subsidence is indicated. This is supported by the presence of locally diverging reflectors. Development of the northern subbasin also shows a localized increase in the subsidence rate of the seaward part north of the IRS. Upwelling-related deposits in Site 679 correlate with this sequence and help to establish its age as Pliocene to early Pleistocene.

\section{Sequence L8}

Sequence L8 is thin and is restricted areally (Fig. 14). Reflectors have moderate amplitude and continuity and onlap to the north, east, and west. The contourite mound noted in sequence L6 forms the seaward boundary. Onlapping reflectors indicate low-energy deposition. The similarity of seismic character and shape to sequence L7 suggests that sequence L8 is probably composed of upwelling-related deposits. Diverging reflectors can be seen locally, which indicates syn-depositional subsidence. Geometry of sequence L8 consists of a single lens-shaped depocenter that is elongated parallel to the trench axis. The lack of definition of the southern flank indicates continued relative subsidence to the south. Sequence L8 does not extend far enough landward to have been penetrated at Site 679 , but dating of the adjacent sequences suggests an age of either late Pliocene or early Quaternary.

\section{Sequence L9}

Sequence L9 (Fig. 15) is similar to sequence L8, except that it is broader and extends farther north and slightly farther landward. It also is interpreted as upwelling related. The isochron map shows two depocenters that are separated by an area of thin sediment cover; this coincides with the LR. Basal reflectors onlap away from the depocenters. Erosional truncation of reflectors visible in line 14 (Plate 1A, 0700-0730 UTC) indicates recent subsidence on both sides of a ridge defined by the southward onlap of sequence L9 near Site 679 (Fig. 15). The presence of southward-onlapping reflectors in line 22 (Plate 1C, 1130 UTC) indicates that subsidence of the southernmost part of the study area ceased. Correlation with Site 679 indicates a Quaternary age for these deposits.

A composite isochron of sequences L3 through L9 (Fig. 16) reveals a symmetry that we did not see in individual sequences. The map represents the thickness of the undeformed section above the 8- to 11-Ma unconformity. The external form is that of a southward-dipping trough. The general thickening southward indicates relative subsidence south from late Miocene to the Holocene. The axis of this section is parallel to the trench axis. We observed another depocenter in the northeastern part of the study area; its limits are poorly constrained by available data.

\section{Migration of Depocenters}

In the Lima Basin, the depocenters in various sequences have shifted through time. This migration is illustrated in Fig. 17. A general trend of landward shifting is evident in sequences L3 through L7. We attributed this to relative subsidence of the landward part of the basin. Because of a change in the mechanism controlling deposition, this landward shift is not evident in sequences L8 and L9. Relative subsidence rates were the predominant force in sequences L3 through L6, while the deposition of sequences L7, L8, and L9 was controlled by the contourite mound in sequence L6. This mound acted as a seawardbounding structural element behind which younger sediments were deposited.

Shifts in the relative positions of the depocenters parallel to the margin can also be seen. While we observed both northward and southward shifting, movement was more southerly.

\section{YAQUINA BASIN}

The strata in the Yaquina Basin comprise five sequences, which are outlined in Table 2. A general discussion of the attributes of these sequences follows.

\section{Sequence Y1}

Sequence Y1 is composed of parallel reflectors of high amplitude and fair-to-good continuity (e.g., line 1, Plate 1D). The upper events are generally conformable, although erosional truncation is evident locally. Because of poor resolution, we did not try to define the base of this sequence. Locally, these higher-amplitude reflectors are underlain by a zone of low-amplitude reflectors that may represent either internal reflections or another underlying sequence. Based on drilling results at Site 683 , sequence Y1 was interpreted as shelf deposits of middle Eocene age. We suggest that this sequence correlates with sequence L1 in the Lima Basin, although the data do not allow definitive correlation.

The structure map at the top of sequence Y1 (Fig. 18) shows that major faults trend north-south parallel to the trench. However, a subordinate system of faults trends west-northwest/eastsoutheast. This is similar to the pattern noted in the Lima Ba$\sin$.

\section{Sequence Y2}

Reflectors in sequence Y2 are generally subparallel and have fair-to-good continuity. Locally, chaotic relationships are evident and result from either poor imaging or disruption (e.g., line 1, Plate 1D). Amplitude varies and generally increases toward the top of the sequence. Where the sequence is particularly thick, its lower part shows little reflectivity. This may indicate slow, uniform hemipelagic deposition, although evidence of baselapping, rather than the characteristic sheet draping, suggests oth- 


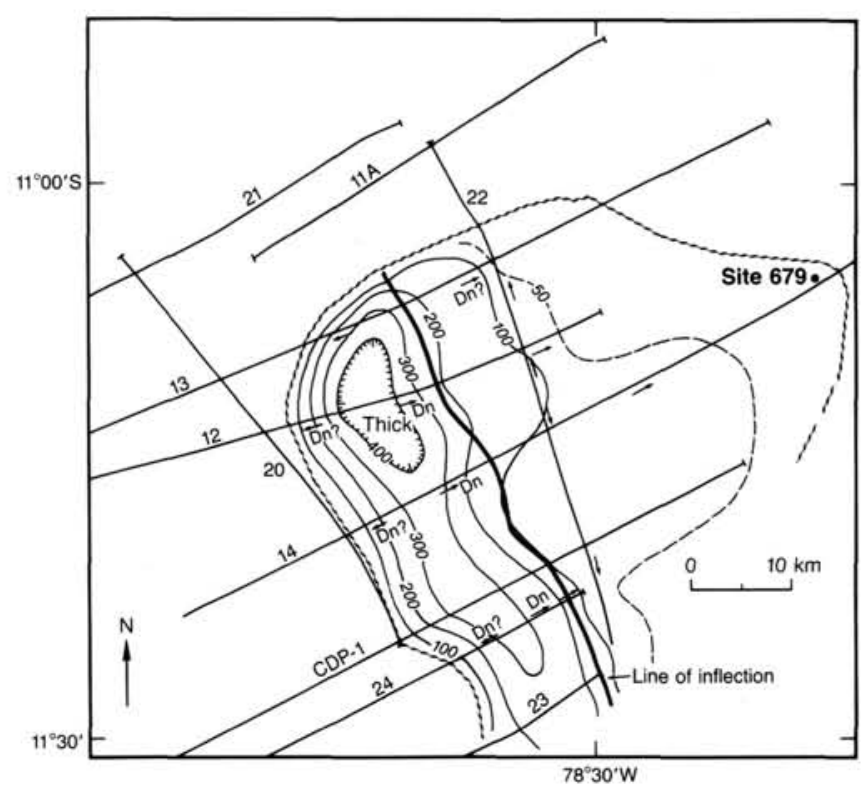

Figure 12. Isochron map of sequence L6. Annotation is the same as that in Figure 6. Note the inflection between the landward and seaward parts of the sequence, indicated by the heavy line. We believe that this inflection marks the landward extent of contourites. Contours are in milliseconds of two-way time. Contour interval is $100 \mathrm{~ms}$. Dashed contours are $50 \mathrm{~ms}$. See text for discussion.

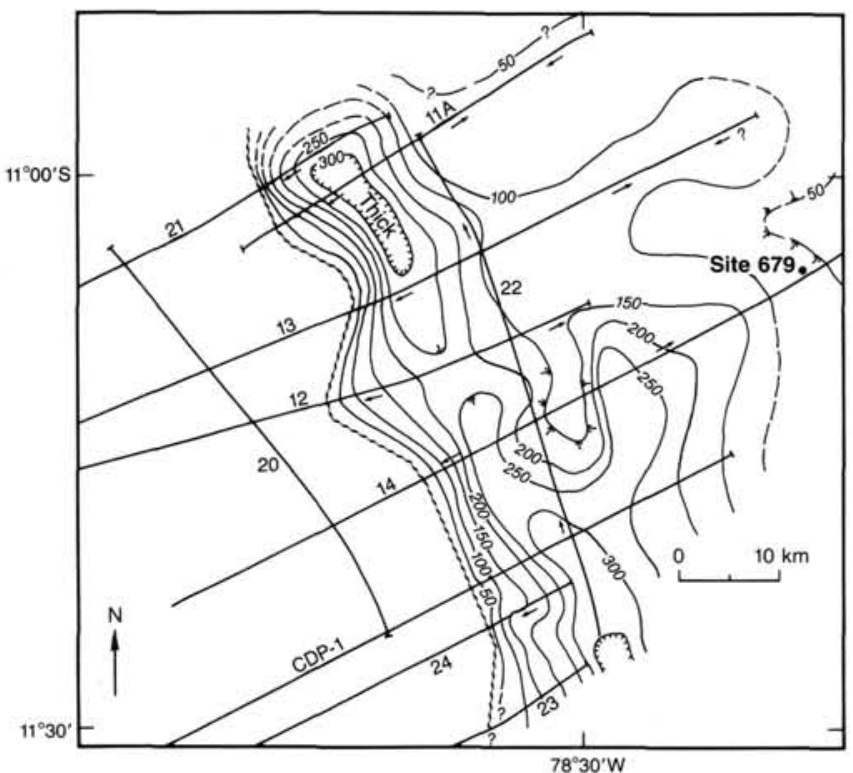

Figure 13. Isochron map of sequence L7. Annotation is the same as that in Figure 6. Contours are in milliseconds of two-way time. Contour interval is $50 \mathrm{~ms}$. See text for discussion.

erwise. This observation could also be an artifact created by scattering and dispersion of the signal related to pervasive structural disruption. Based on the similarity of the seismic character to other sequences, we suggest that these strata are composed of upwelling-related deposits. The high-amplitude reflectors at the top of the sequence may indicate an increase in the energy of the depositional environment. This also may relate to a shoaling of the sequence. Alternatively, an increase in grain size of the sediment source may be caused by elevated stream gradients in response to tectonic uplift. Upper events generally conform to the

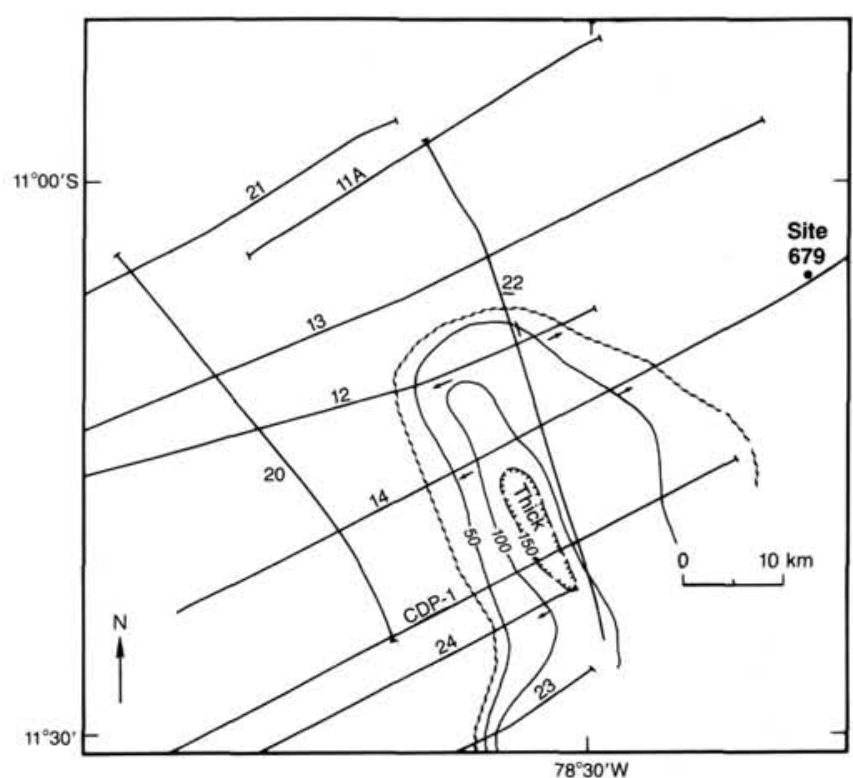

Figure 14. Isochron map of sequence L8. Annotation is the same as that in Figure 6. Contours are in milliseconds of two-way time. Contour interval is $\mathbf{5 0} \mathrm{ms}$. See text for discussion.

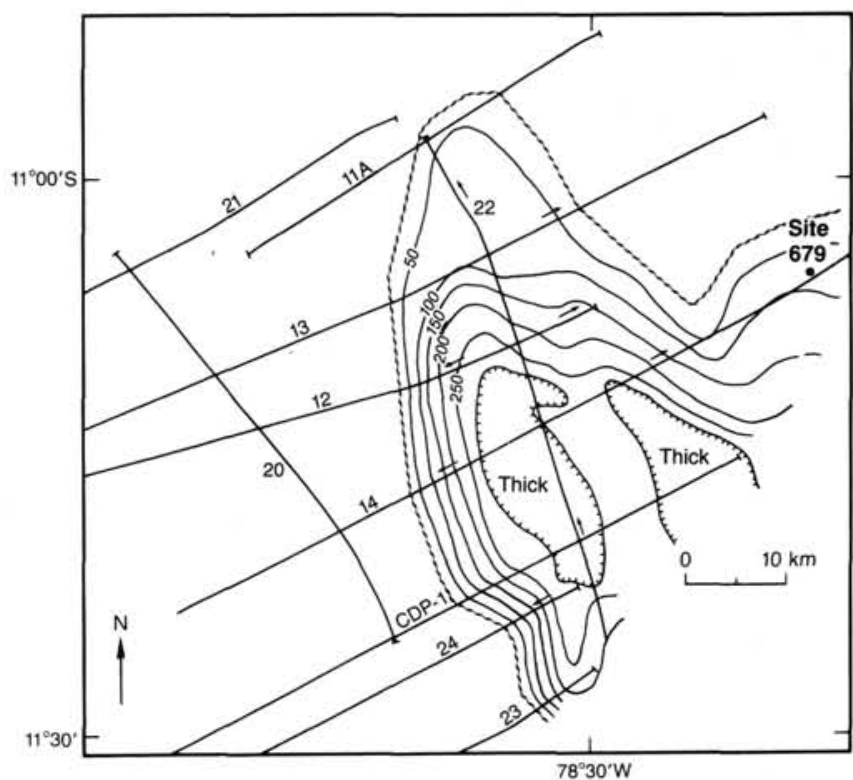

Figure 15. Isochron map of sequence L9. Annotation is the same as that in Figure 6. Contours are in milliseconds of two-way time. Contour interval is $\mathbf{5 0} \mathrm{ms}$. See text for discussion.

sequence Y2 boundary, although some truncation also occurs locally.

The isochron map of sequence Y2 (Fig. 19) shows a series of isolated depocenters that coincide with downthrown fault blocks. While a general conformity exists between the structure and isochron maps, significant discrepancies do occur. This suggests substantial shifts in the structural surface since deposition. Note that the isochron map shows that the northern part of the basin was structurally high during deposition of this sequence. This is not the case today. Fair correspondence between the southeastern high and the section without sequence Y2 sediments (Fig. 19) contrasts with the lack of correspondence noted in the north. 


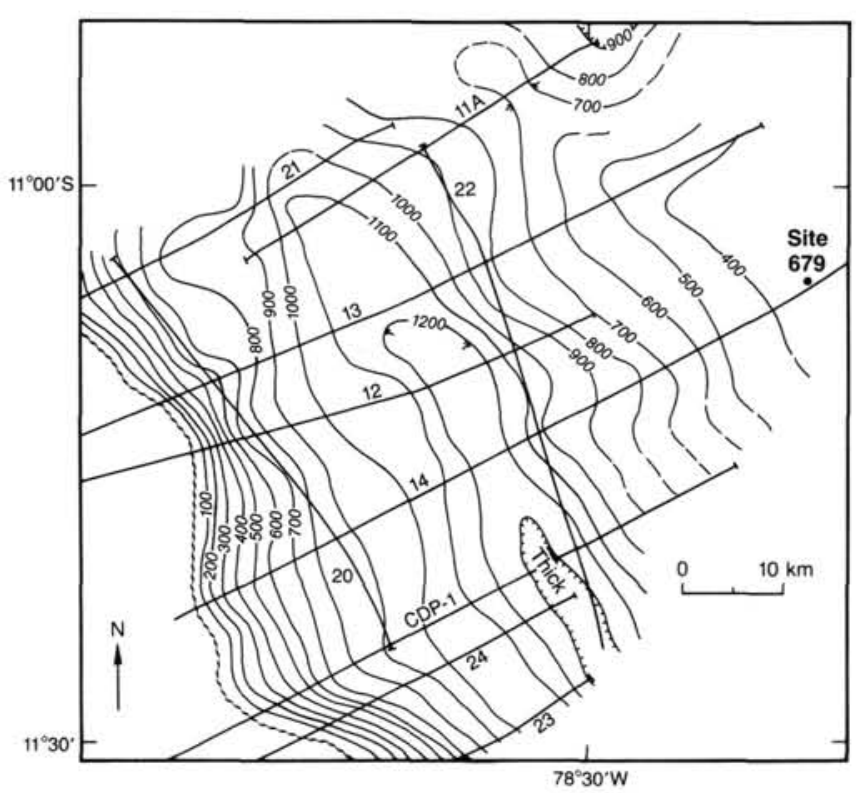

Figure 16. Composite isochron of sequences L3 through L9, representing the total sediment thickness above the 8-11-Ma unconformity. Contours are in milliseconds of two-way time. Contour interval is $100 \mathrm{~ms}$. See text for discussion.

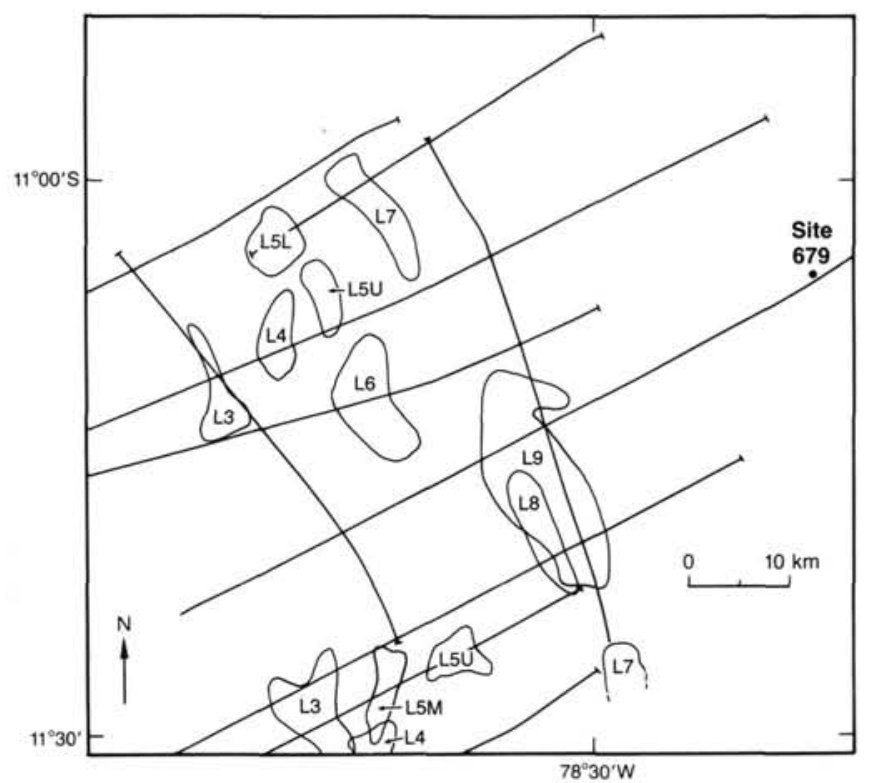

Figure 17. Depocenter migration within the Lima Basin. The depocenters associated with the various individual sequences, as indicated by the largest closing isochron contour line, show a well-developed landward (eastward) migration through time. Lateral migration along the margin is also evident, although the trend is less uniform. Only the seawardmost depocenters are shown for sequences having more than one.

This indicates that the northern part of the basin subsided in relation to the southern part. Similar variations can be seen on a local scale. This phenomenon can best be seen in line 1 (Plate 1D). Here, the thickest part of sequence Y2 occurs on the flank of the basement high (0045 UTC). However, today's structural low (0200 UTC) indicates that the sequence is relatively thin. While this could be related to limited progradation from a local sediment source, low-energy deposition contradicts this.

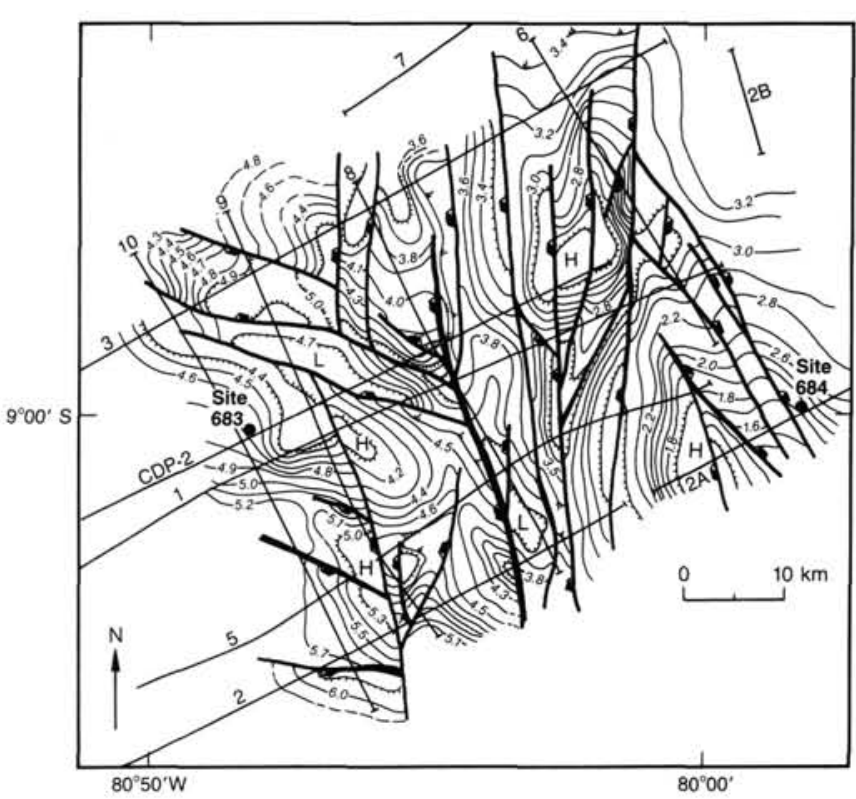

Figure 18. Time-structure map at top of sequence Y1. Fault patterns have been greatly simplified. Contours are in seconds of two-way time. Contour interval is $0.1 \mathrm{~s}$. See text for discussion.

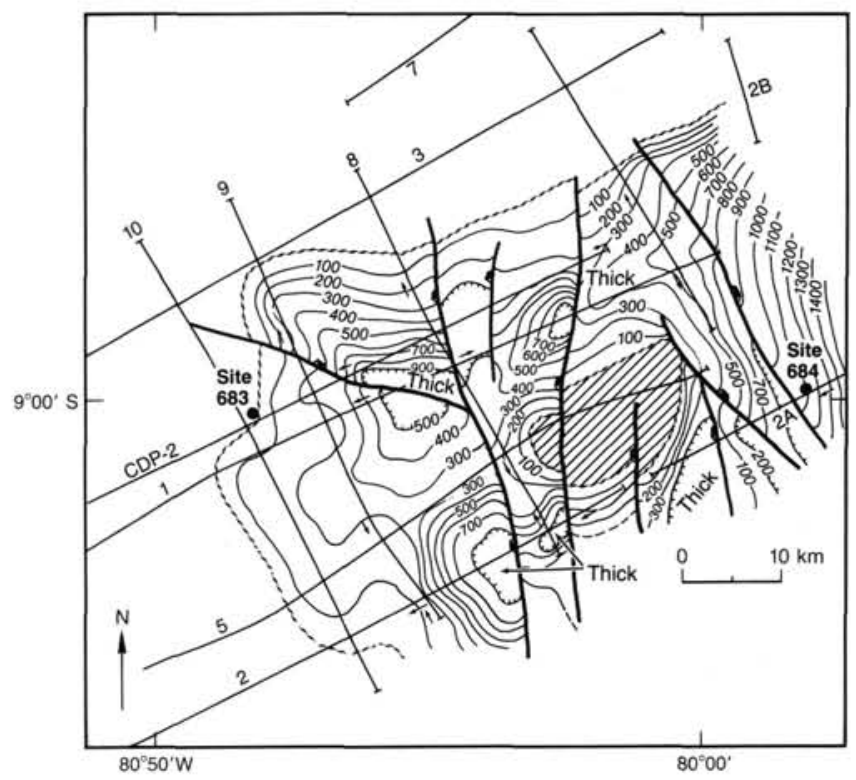

Figure 19. Isochron map of sequence Y2. Annotation is the same as that in Figure 6. Critical faults are shown to illustrate the correspondence of the depocenters to the downthrown fault blocks, indicating fault-controlled deposition. All faults are assumed to be vertical. Hatched areas indicate the absence of sediments of this age. Contours are in milliseconds of two-way time. Contour interval is $100 \mathrm{~ms}$. See text for discussion.

The strata of sequence Y2 were not penetrated at Site 683 nor at Site 684. Correlation with the unconformities at these two locations indicates deposition in the interval between middle Eocene and middle Miocene time. We speculate that the sequence is early Miocene in age, although it may be older. Although Oligocene sediments are usually absent along the margin, some Oligocene sediments were recovered at Site 682 trenchward of the Lima Basin. The apparent lack of a correlative sequence in 
Table 2. Profile of seismic sequences at Yaquina Basin.

\begin{tabular}{|c|c|c|c|c|c|}
\hline \multirow[b]{2}{*}{ Sequence } & \multicolumn{2}{|c|}{ Terminations $^{\mathrm{a}}$} & \multirow{2}{*}{$\begin{array}{c}\text { Seismic } \\
\text { characteristics }\end{array}$} & \multirow[b]{2}{*}{ Facies } & \multirow[b]{2}{*}{ Age } \\
\hline & upper & lower & & & \\
\hline Y1 & $\mathrm{C} / \mathrm{Te}$ & $?$ & $\begin{array}{l}\text { Subparallel, disrupted, high } \\
\text { amplitude, fair-to-good } \\
\text { continuity. }\end{array}$ & $\begin{array}{l}\text { Shelf } \\
\text { deposits }\end{array}$ & $\begin{array}{l}\text { middle } \\
\text { Eocene }\end{array}$ \\
\hline $\mathrm{Y} 2$ & $\mathrm{Te} / \mathrm{C}$ & On/Dn(?) & $\begin{array}{l}\text { Subparallel, disrupted, } \\
\text { amplitude and continuity } \\
\text { variable, increasing } \\
\text { upward, locally chaotic, } \\
\text { basin fill. }\end{array}$ & $\begin{array}{l}\text { Low-energy } \\
\text { turbidites, } \\
\text { upwelling } \\
\text { deposits(?) }\end{array}$ & $\begin{array}{c}\text { early } \\
\text { Miocene- } \\
\text { Oligocene } \\
(?)\end{array}$ \\
\hline Y3 & $\mathrm{C} / \mathrm{Te}$ & On & $\begin{array}{l}\text { Subparallel, disrupted } \\
\text { amplitude and continuity, } \\
\text { variable, increasing } \\
\text { upward, basin fill. }\end{array}$ & $\begin{array}{l}\text { Low-energy } \\
\text { turbidites, } \\
\text { upwelling } \\
\text { deposits }\end{array}$ & $\begin{array}{l}\text { middle } \\
\text { Miocene }\end{array}$ \\
\hline Y4 & $\mathrm{Te} / \mathrm{C}$ & $\mathrm{Dn} / \mathrm{On}$ & $\begin{array}{l}\text { Lenticular to hummocky, } \\
\text { disrupted, fair } \\
\text { continuity and amplitude, } \\
\text { mounded. }\end{array}$ & $\begin{array}{l}\text { High-energy } \\
\text { basin fill, } \\
\text { turbidites, } \\
\text { upwelling } \\
\text { deposits }\end{array}$ & $\begin{array}{c}\text { late } \\
\text { Miocene- } \\
\text { Pliocene }\end{array}$ \\
\hline Y5 & $C(?)$ & $\mathrm{On} / \mathrm{Dn}$ & $\begin{array}{l}\text { Subparallel, locally } \\
\text { disrupted, locally } \\
\text { wavy, low amplitude, } \\
\text { fair continuity. }\end{array}$ & $\begin{array}{l}\text { Low-energy } \\
\text { turbidites, } \\
\text { upwelling } \\
\text { deposits }\end{array}$ & $\begin{array}{l}\text { late } \\
\text { Pliocene- } \\
\text { Quaternary }\end{array}$ \\
\hline
\end{tabular}

${ }^{\mathrm{a}} \mathrm{C}=$ conformable; $\mathrm{Te}=$ erosional truncation; $\mathrm{Dn}=$ downlap; $\mathrm{On}=$ onlap.

the Lima Basin indicates that post-Eocene development of the Yaquina Basin may have started somewhat earlier. However, drilling in the Lima Basin did not penetrate deep enough to confirm this.

\section{Sequence Y3}

Sequence Y3 contains subparallel to wavy reflectors of variable continuity and amplitude. The lower reflectors exhibit baselap, probably onlap in most cases, based on internal reflector geometry. Downlap also may occur locally. Reflector amplitude increases upward within sequence Y3. Onlap of the basal reflectors and variable amplitude indicates low-energy deposition. Sediments from this sequence that were recovered at Sites 683 and 684 represent middle Miocene upwelling-related deposits.

The isochron map of this sequence (Fig. 20) shows two linear north-south trends of thin sediment cover in the landward part of the study area. This trend is subparallel with that of the major faults in the area and probably represents thin sedimentation over the structural high separating the Yaquina and Trujillo basins (the upper-slope ridge of Thornburg and Kulm, 1981). We assumed that a similar area of thin or no sediment cover in sequence Y2 (Fig. 19) represents the same feature. Again, deposition controlled by faults is indicated by the location of the thickest sediment accumulations on downthrown fault blocks. Fewer changes in the thickness of sequence Y3 suggests that tectonic activity was more restricted.

\section{Sequence Y4}

Initial deposition in this sequence marks a major change in the nature of deposition in the basin. This unit is characterized by lenticular to hummocky reflectors that are often disrupted. Basal reflectors downlap in both seaward and landward directions, often at high angles (line 1, Plate 1D, 0100-0300 UTC). This also is illustrated in survey line CDP-2 at $22 \mathrm{~km}$ and about $3.5 \mathrm{~s}$ (see von Huene et al., 1985; von Huene et al., 1987b). Locally, reflectors show a divergent relationship. These trends indicate rapid deposition into a subsiding area. An alternative possibility is that these reflectors may represent contourites, such as those interpreted in the Lima Basin. However, the geometry along the strike lines is similar to that in the dip lines, and the isochron map (Fig. 21) does not show a linear trend. The thick and thin areas are isolated features, similar to those noted in the sequence Y2 isochron map (Fig. 19). The most prominent regional feature is a well-developed, northward-thickening trend (Fig. 21; line 8, Plate 1E). This is further reflected by the landward trends. Today, these trends demonstrate a northeast-southwest orientation, rather than the north-south trend in older sequences. This suggests that the large relative subsidence of the northern part of the basin occurred during deposition of sequence Y4.

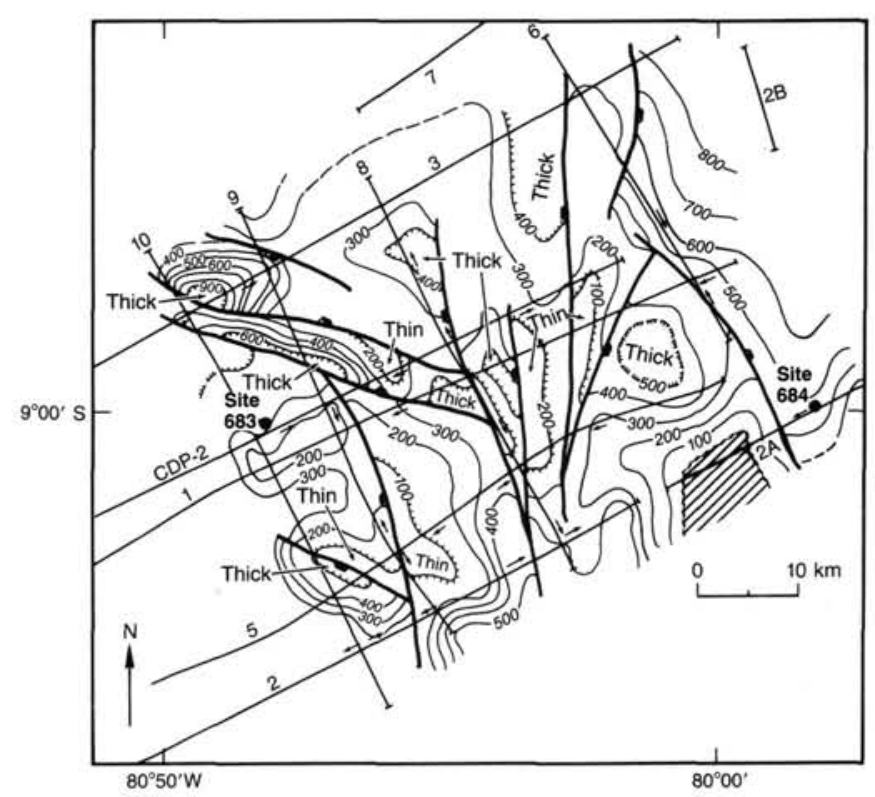

Figure 20. Isochron map of sequence Y3. Annotation is the same as that in Figure 6. Critical faults illustrate the correspondence of the depocenters to the downthrown fault blocks, indicating fault-controlled deposition. All faults are assumed vertical. Hatched areas indicate the absence of sediments of this age. Contours are in milliseconds of two-way time. Contour interval is $100 \mathrm{~ms}$. See text for discussion. 


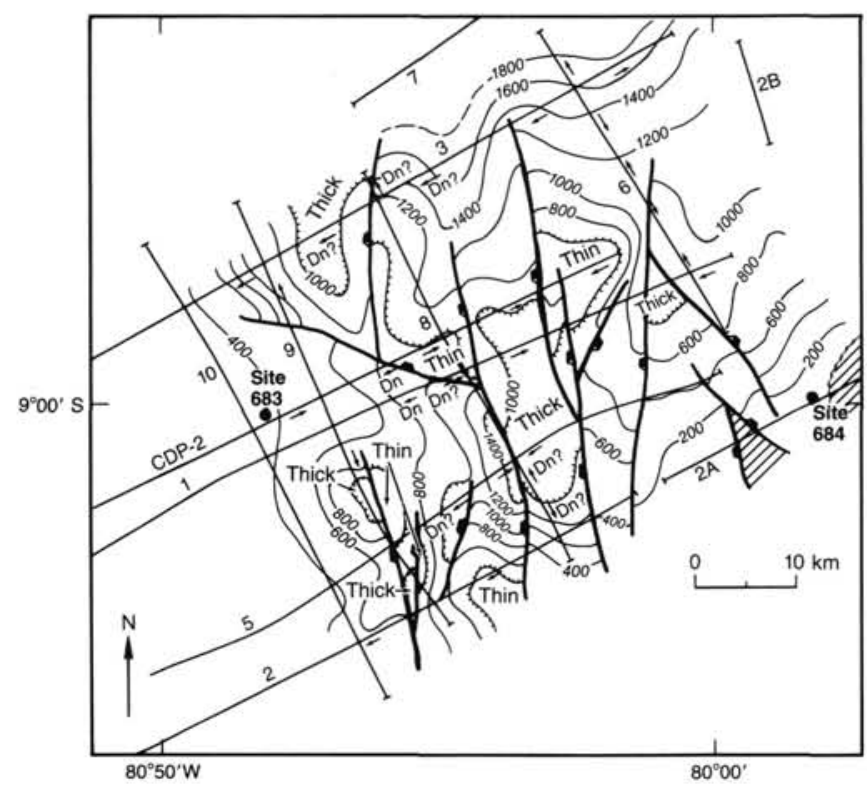

Figure 21. Composite isochron map of sequences Y4 and Y5. Annotation is the same as that in Figure 6. Critical faults illustrate the correspondence of the depocenters to the downthrown fault blocks, indicating fault-controlled deposition. All faults are assumed to be vertical. Hatched areas indicate the absence of sediments of this age. Contours are in milliseconds of two-way time. Contour interval is $200 \mathrm{~ms}$. See text for discussion.

Sequence Y4 seems more structurally disrupted than adjacent sequences. While this probably results from the complex internal reflector geometry, faulting can be seen locally but does not seem to penetrate the underlying sequences. This may be the result of low data resolution at this level. These faults also may represent growths related to the rapid deposition of sequence Y4.

At Site 683, the upwelling-related deposits and turbidites that correlated with this sequence were assigned a Pliocene age. The prograding nature of this sequence, indicated by downlapping reflector geometry, suggests that sediments are older for initial sedimentation of the sequence near point of reversal in the direction of downlap (Fig. 21; line 1, Plate 1D, 0230 UTC). Because Site 683 is located at the edge of Y4, the middle Miocene to Pliocene hiatus indicates that more time elapsed between the oldest Y4 deposits and those of sequence Y3. A similar situation can be seen at Site 684. Northward tilting of initial deposition of sequence Y4 may have resulted in sediment bypassing the Site 684 location. Results from industry wells also indicate shallow-water deposition at this location. A eustatic low stand may have resulted in subaerial exposure. In both cases, initial deposition late in the history of sequence Y4 sedimentation is implied. Based on this, we assigned a late Miocene to Pliocene age to this sequence.

\section{Sequence Y5}

Sequence Y5 consists of subparallel reflectors having fair-togood continuity but low amplitude. This probably results from a local gas-hydrate layer. Such features typically indicate the reduction of impedance contrasts, which results in the damping of reflector amplitudes (Macleod, 1982). This also may be an artifact caused by the use of automatic gain control (AGC) scaling during processing. Basal terminations appear to onlap. Upper terminations are obscured by the bubble pulse. This type of configuration indicates low-energy turbidites, which was confirmed by drilling at Site 683 , where we encountered interbedded turbidites and upwelling-related deposits. We did not construct a separate isochron map of this unit. Instead, we included it in the isochron of sequence Y4 (Fig. 21). Results from Sites 683 and 684 indicate a late Pliocene to Quaternary age for this sequence.

\section{DISCUSSION}

Our seismic-reflection and well data show that significant differences exist in the factors controlling the depositional histories of the Lima and Yaquina basins. Deposition in the Lima Basin appears to have been controlled mainly by sedimentary processes and relative subsidence rates. In the Yaquina Basin, a more active tectonic influence is indicated. The strata above the unconformity in the Lima Basin (sequences L3 through L9) are relatively undeformed. In contrast, strata in the Yaquina Basin are strongly deformed throughout the section. This suggests that the tectonic and depositional histories of the two basins differ in the magnitude and timing of the events experienced.

Because sedimentation is closely linked with tectonics, this observation implies that the nature and shape of the sequences in the Yaquina Basin should differ distinctly from those in the Lima Basin. This is confirmed by the isochron maps of the two basins. In the Lima Basin, the sequences tend to be elongated parallel to the trench and relatively broad and smooth. This indicates laterally consistent deposition. Yaquina Basin sequences are not oriented consistently in relation to the trench. These sequences commonly contain many lateral variations in sediment thickness.

Kulm et al. (this volume) indicate that rapid subsidence occurred along the Peruvian continental margin. The sequence L2 structure map (Fig. 6) shows that the southern structural subbasin in the Lima Basin study area coincides with a part of the SR depicting absence of sequence L2 sediments. This suggests that the SR later became a locus of subsidence. This agrees with Kulm et al.'s (1981) findings that from the late Miocene to the Holocene, the seaward part of the margin subsided more than the landward regions. Our data indicate that this subsidence did not occur uniformly across the area. During this period, the southern part of the basin subsided more than the northern part. This is supported by the more obvious absence of L2 strata along the southern part of the SR (Fig. 6). This observation suggests that the southern area was structurally higher than the northern part at the time of the unconformity. Today, the southern part of the SR is structurally lower. In addition to this general trend of southward subsidence, significant local variations in relative subsidence occurred between and during the deposition of the various sequences. We believe that variation in the relative rate of subsidence was the major factor controlling deposition during the early history of the Lima Basin (sequences L3 through L5), while contour currents were the dominant influence in the later history.

The onset of rapid subsidence is indicated between sequences L5U and L6, which correlates with the beginning of the Pliocene. In sequence L5U and those underlying it, a seismic signature characteristic of shelf deposits is common. This is not the case with the younger sequences. The timing of this transition corresponds with a marked decrease in the rate of subduction (Cande, 1985).

The underlying structures, prominently displayed on structure maps and the sequence L2 isochron, have not influenced deposition of the younger sequences much. Isochron maps of these younger sequences do show some tectonic influence, with the pattern of variations in subsidence rates being related to 
movements along structural trends. However, this influence is minimal. The lack of a bounding structural element on the seaward flank of the basin during deposition of sequences L3 through L6 and the prominent landward-downlapping reflectors indicate that deposition of these units was not structurally controlled. The seismic signature characteristic of contourites in sequence L6 (Mitchum and Vail, 1977) suggests that contour currents acted as the seaward-bounding element during the early Pliocene. The sediment was entrained downslope and reworked along the margin. This ridge later provided a seaward-bounding element for sequences L7, L8, and L9.

The nature of these contour currents is unknown at present. Thornburg and Kulm (1981) suggested that an existing shallow undercurrent $(<400 \mathrm{~m})$ (Brockmann et al., 1980), may have been responsible. However, this is not a satisfactory answer. The rapid subsidence rates that occurred during the Neogene $(>350$ $\mathrm{m} / \mathrm{m}$.y. locally) (Kulm et al., this volume) would quickly remove the basin from the influence of these shallow currents. This hypothesis also implies that contourite deposition should be apparent in Holocene sediments, which is not the case. However, recently collected hydrographic data along the Peru margin indicate the presence of contour currents at water depths up to $730 \mathrm{~m}$ and velocities up to $25 \mathrm{~cm} / \mathrm{s}$ (L. Kulm, pers. commun., 1987). Future studies may demonstrate the existence of additional currents at even greater depths. Because the interpreted contourites are limited in time and do not appear in Holocene deposits, we suggest that these contourites result from oceanographic conditions not present today. Contour currents active along the Peruvian continental margin may provide limited insight into the processes responsible for the observed contourite deposits. Note that the contourites in sequence L6 are early Pliocene in age, which corresponds to a major eustatic transgression (Vail et al., 1977). Melting polar ice during this event would provide a major source of cold, dense water and thus may have resulted in the intensification of contour currents. Similar occurrences related to upwelling deposition during the Pleistocene along the Peruvian continental margin have been reported by Reimers and Suess (1983).

The Yaquina Basin shows an evolution influenced by tectonism. Depositional forces are different from those evident in the Lima Basin. The most obvious manifestation is the extremely disrupted nature of the reflectors in the Yaquina Basin, which suggests a strong and persistent tectonic influence. The isolated depocenters depicted on the isochrons in sequence Y4 appear to be largely controlled by faults. The reflection character of sequence Y4 indicates high-energy deposition. This may be related to exposure of the shelf landward of the Yaquina Basin during a eustatic low stand. Contourite deposition does not appear to affect the Yaquina Basin significantly. Dividing the late Miocene-Holocene strata into only two sequences, when eight sequences were identified in the Lima Basin, suggests less variation in the depositional processes in the Yaquina. Although this is also due in part to lower resolution caused by structural disruption and generally poorer data quality.

Our data indicate generally landward and southward migrations of the depocenters of the various sequences through time in the Lima Basin. A similar northward progression is documented in the Yaquina Basin. The reasons for these phenomena are not clear. We are tempted to relate this progression to the subcrustal passage of the Nazca Ridge, which may be a workable hypothesis for the Lima Basin. The presence of a well-developed east-west trend in many of the sequences supports this hypothesis. However, the opposing movement in the Yaquina Basin suggests that other processes are also influential. Perhaps the basement high that separates the two basins acted as a cen- ter of uplift during the Neogene. Or this high may have controlled the relative rates of subsidence. We are not sure which mechanism was most dominant.

\section{CONCLUSIONS}

1. The Lima and Yaquina basins experienced significantly different Neogene depositional and structural histories.

2. Subsidence has not occurred uniformly across the entire margin. Substantial local variations in the subsidence rate are evident. This can be seen best in the Lima Basin.

3. Deposition in the Lima Basin was controlled primarily by variations in the relative subsidence rates in its early history (Miocene), while contour currents controlled subsequent deposition. In the Yaquina Basin, Neogene faulting played a leading role.

4. The depocenters of the sequences in both areas migrated through time. Those in the Lima Basin moved southward and landward, while those in the Yaquina Basin shifted northward. We believe that the landward movements in the Lima Basin result from relative subsidence of the landward part of the basin. The northward and southward components have not yet been explained.

\section{ACKNOWLEDGMENTS}

Special thanks to Vern Kulm, Richard Matson, Todd Thornburg, and Roland von Huene, whose helpful comments greatly improved this manuscript. Copies of CDP-1 and CDP-2 were provided by Roland von Huene and John Miller. Data acquisition and processing were supported by JOI. Preparation of this paper was supported by USSAC.

\section{REFERENCES}

Brockmann, C., Fahrbach, E., Huyer, A., and Smith, R. L., 1980. The poleward undercurrent along the Peru coast: $5^{\circ}$ to $15^{\circ} \mathrm{S}$. Deep Sea Res., 27A:847-856.

Cande, S. C., 1985. Nazca-South American plate interactions since 50 My b.p. to present. In Hussong, D. M. et al. (Eds.), Atlas of the Ocean Margin Drilling Program, Peru Continental Margin, Region $V I$ : Woods Hole (Marine Science International), 14.

Kulm, L. D., Schrader, H., Resig, J. M., Thornburg, T. M., Masias, A., and Johnson, L., 1981. Late Cenozoic carbonates on the Peru continental margin: lithostratigraphy, biostratigraphy and tectonic history. In Kulm, L. D., Dymond, J., Dasch, E. J., and Hussong, D. M. (Eds.) Nazca Plate: Crustal Formation and Andean Convergence. Geol. Soc. Am. Mem., 154:469-508.

Macleod, M. K., 1982. Gas hydrates in ocean bottom sediments. AAPG Bull., 66:2649-2662.

Mitchum, R. M., and Vail, P. R., 1977. Seismic stratigraphic interpretation procedure. In Payton, C. E. (Ed.), Seismic Stratigraphy-Applications to Hydrocarbon Exploration: AAPG Mem., 26:135-143.

Mitchum, R. M., Vail, P. R., and Sangree, J. B., 1977. Stratigraphic interpretation of seismic reflection patterns in depositional sequences. In Payton, C. E. (Ed.), Seismic Stratigraphy-Applicatoins to Hydrocarbon Exploration: AAPG Mem., 26:117-134.

Reimers, C., and Suess, E., 1983. Spatial and temporal patterns of organic matter accumulation on the Peru continental margin. In Suess, R., and Thiede, J. (Eds.), Coastal Upwelling: Its Sedimentary Record: New York (Plenum Press), 311-337.

Sangree, J. B., and Widmier, J. M., 1977. Seismic interpretation of clastic depositional facies. In Payton, C. E. (Ed.), Seismic Stratigraphy-Applications to Hydrocarbon Exploration: AAPG Mem., 26: $165-184$.

Shipley, T. H., Buffler, R. T., and Watkins, J. S., 1978. Seismic stratigraphy and geologic history of the Blake Plateau and the adjacent western Atlantic continental margin. AAPG Bull., 62:792-812. 
Thornburg, T. M., 1985. Multichannel seismic interpretations-shelf and upper slope basins. In Hussong, D. M., and Kulm, L. D. (Eds.), Ocean Margin Drilling Program, Regional Atlas Series, Atlas VI: Woods Hole (Marine Science International).

Thornburg, T. M., and Kulm, L. D., 1981. Sedimentary basins of the Peru continental margin: structure, stratigraphy and tectonics from $6^{\circ} \mathrm{S}$ to $16^{\circ} \mathrm{S}$ latitude. In Kulm, L. D., Dymond, J., Dasch, E. J., and Hussong, D. M. (Eds.), Nazca Plate: Crustal Formation and Andean Convergence. Geol. Soc. Am. Mem., 154:393-422.

Vail, P. R., Mitchum, R. M., and Thompson, S., 1977. Global cycles of relative changes of sea level. In Payton, C. E. (Ed.), Seismic Stratigraphy-Applications to Hydrocarbon Exploration: AAPG Mem., 26:83-97. von Huene, R., Kulm, L. D., and Miller, J., 1985. Structure of the frontal part of the Andean convergent margin. J. Geophy. Res., 90: 5429-5442.

von Huene, R., Suess, E., Emeis, K.-C., and Leg 112 Scientific Party, 1987a. Convergent tectonics and coastal upwelling: a history of the Peru continental margin. Episodes, 10:87-93.

von Huene, R., Kulm, L. D., Miller, J., and Hussong, D. M., 1987b. The Peru Continental Margin, Record Sections 2 and 3. In von Huene (Ed.), Seismic Images of Modern Convergent Margin Tectonic Structure: AAPG Stud. Geol., 26:37-42.

Ms 112A-105 